OPEN ACCESS

Edited by:

Anna Siebel,

Universidade Comunitária da Região

de Chapecó, Brazil

Reviewed by:

Jason Bondoc Alipio,

University of Maryland, Baltimore,

United States

Lisa Baumann,

Heidelberg University, Germany

${ }^{*}$ Correspondence: Victoria P. Connaughton vconn@american.edu

Specialty section: This article was submitted to Experimental Pharmacology and Drug

Discovery,

a section of the journal

Frontiers in Pharmacology

Received: 16 December 2021

Accepted: 28 January 2022

Published: 28 February 2022

Citation:

Cohen A, Popowitz J, Delbridge-Perry M, Rowe CJ and Connaughton VP (2022) The Role of Estrogen and Thyroid Hormones in

Zebrafish Visual System Function.

Front. Pharmacol. 13:837687.

doi: 10.3389/fphar.2022.837687

\section{The Role of Estrogen and Thyroid Hormones in Zebrafish Visual System Function}

\author{
Annastelle Cohen ${ }^{1}$, Jeremy Popowitz ${ }^{1}$, Mikayla Delbridge-Perry ${ }^{2}$, Cassie J. Rowe ${ }^{1,3}$ and \\ Victoria P. Connaughton ${ }^{1,3 *}$
}

${ }^{1}$ Department of Biology, American University, Washington, DC, WA, United States, ${ }^{2}$ Department of Chemistry, American University, Washington, DC, WA, United States, ${ }^{3}$ Center for Neuroscience and Behavior, American University, Washington, DC, WA, United States

Visual system development is a highly complex process involving coordination of environmental cues, cell pathways, and integration of functional circuits. Consequently, a change to any step, due to a mutation or chemical exposure, can lead to deleterious consequences. One class of chemicals known to have both overt and subtle effects on the visual system is endocrine disrupting compounds (EDCs). EDCs are environmental contaminants which alter hormonal signaling by either preventing compound synthesis or binding to postsynaptic receptors. Interestingly, recent work has identified neuronal and sensory systems, particularly vision, as targets for EDCs. In particular, estrogenic and thyroidogenic signaling have been identified as critical modulators of proper visual system development and function. Here, we summarize and review this work, from our lab and others, focusing on behavioral, physiological, and molecular data collected in zebrafish. We also discuss different exposure regimes used, including long-lasting effects of developmental exposure. Overall, zebrafish are a model of choice to examine the impact of EDCs and other compounds targeting estrogen and thyroid signaling and the consequences of exposure in visual system development and function.

Keywords: Danio rerio (zebrafish), retina, estradiol, T3, T4, development

\section{INTRODUCTION}

The impacts of endocrine manipulation often result in a cascade of effects at the biomolecular level, reaching outside a single pathway, and many non-endocrine organs, such as kidney and gut, secrete hormones. Further, neuronal development, and sensory system development, are dependent on hormones. Recent work has revealed the importance of thyroid hormones (THs), estrogen, and their receptors in visual system development. Both hormones are able to cross cell membranes, bind intracellular receptors, and affect subsequent pathways and/or gene expression. Disruption of either estrogenic or thyroidogenic pathways, by clinical treatments or environmental endocrine disrupting compounds (EDCs), impact the visual system directly or indirectly, and early developmental exposure to endocrine disruptors can have long-term deleterious effects. In addition to the epidemiological significance of endocrine disruption in humans, these effects also impose consequences on ecological systems at a population level as visual perception is essential for the success, survival, and reproduction of many organisms. The purpose of this review is to compare/ contrast the role(s) of thyroid hormone and estrogen in the proper function and development of the visual system in the zebrafish animal model. 


\section{Zebrafish}

Zebrafish, Danio rerio, a small freshwater tropical fish native to Southeast Asia, are an existing vertebrate model for a variety of disciplines, including endocrinology, toxicology, developmental biology, and vision. Adult zebrafish measure $2.5-4 \mathrm{~cm}$ in length and, due to their small size, can be housed in large numbers at a low-cost relative to other available model organisms. The zebrafish genome has been sequenced in its entirety (https:// www.sanger.ac.uk/data/zebrafish-genome-project/), making this species valuable for investigation of various disorders and disease. Zebrafish have more than 26,000 protein-coding genes and $70 \%$ of human genes have at least one obvious zebrafish orthologue (Howe et al., 2013). Mutant strains and transgenic lines can be easily and quickly produced and assessed using large-scale genetic screens. Further, large clutch sizes of externally developing, transparent embryos are amenable to exposure studies as compounds are administered directly into tank water resulting in behavioral and/or physiological responses that can be recorded.

In addition to the technical and practical advantages of zebrafish, they serve as a powerful model organism for studying visual system development, function, and underlying mechanisms of disease. Zebrafish eyes are similar in anatomy, circuitry, physiology, and gene expression to humans (Bibliowicz et al., 2012). The zebrafish retina contains similar cell types and circuitry to the human retina, and retina-specific diseases observed in humans, such as red color blindness (Brockerhoff et al., 1997) and congenital stationary night blindness (Peachey et al., 2012) occur in and are modeled with zebrafish.

Zebrafish have also been used to study early life and adult effects of hormones, at both organizational and activational levels. Zebrafish nervous and endocrine systems (Tata, 2005) are also similar to humans from development throughout adulthood (Kimmel et al., 1995; Kishida and Callard, 2001; Gerlai, 2016). Studies with EDCs reveal effects on development, reproduction, sensory systems, cell proliferation, and heart formation. EDC exposure has been linked to obesity (Hatch et al., 2010; Heindel et al., 2015), metabolic and reproductive issues (Wada et al., 2007; Casals-Casas and Desvergne, 2011), and neurological disorders (Kajta and Wojtowicz, 2013). Specific to this review, EDCs can affect the brain/neurogenesis (Kishida et al., 2001; Hamad et al., 2007; Pelligrini et al., 2007; Diotel et al., 2013), including negatively impacting the visual system (Dong et al., 2006; Hamad et al., 2007; Wang et al., 2012).

Here, we focus on the specific effects of estrogen and thyroid hormone signaling in retinal development and function. We begin with a general description of eye development and structure in zebrafish and signaling by estrogen and thyroid hormones. We then discuss the role of estrogenic and thyroidogenic signaling in vision. We conclude with a summary of these effects, revealing significant crosstalk among these two systems that is important for proper visual function.

\section{Visual System Development}

Morphogenesis of the zebrafish eye occurs very rapidly between 12 and $24 \mathrm{~h}$ post fertilization (hpf) and the structure of the eyes is thought to be fully realized by $36 \mathrm{hpf}$ (Schmitt and Dowling, 1994;
Schmitt and Dowling, 1999). Within the retina, differentiation first occurs in a ventronasal patch near the optic nerve, and like most other vertebrates, moves from inner to outer retina (Schmitt and Dowling, 1999). At $32 \mathrm{hpf}$, ganglion cells begin to form and the optic nerve exits the retina. By $50 \mathrm{hpf}$, amacrine and horizontal cells in the inner nuclear layer begin to differentiate. Bipolar cells in the inner nuclear layer begin to differentiate at $60 \mathrm{hpf}$, as do rod and cone synaptic terminals. At $74 \mathrm{hpf}$, the zebrafish eye is fully developed (Schmitt and Dowling, 1999). Optokinetic responses can be recorded from zebrafish larvae as young as 4 days postfertilization (dpf) (Neuhauss, 2003; Brockerhoff, 2006), and vision-based optomotor responses are reliably recorded at $7 \mathrm{dpf}$ (Clark, 1981; Bilotta et al., 2002; Bahadori et al., 2003; Orger et al., 2004; Muto et al., 2005) (Figure 1).

The adult zebrafish retina includes four cone types ( $\mathrm{R}-\mathrm{red}$, G-green, B-blue, UV-ultraviolet) arranged in an orderly mosaic. These cone types are present in larval retinas, though the mosaic is less organized (Allison et al., 2010). During embryogenesis, photoreceptors develop at 43-48 hpf and opsins in rods, R and B cones are first detected at $~ 50-52$ hpf (Raymond et al., 1995; Tsujikawa and Malicki, 2004). The presence of four cone types confers rich color processing abilities (Meier et al., 2018), in both larvae and adults, with a diversity of color-evoked responses seen in second-order horizontal cells (Connaughton and Nelson, 2010) as well as third-order amacrine (Torvund et al., 2016) and ganglion cells (Connaughton and Nelson, 2010). Color responses in zebrafish retinal bipolar cells have not been recorded; though anatomical analysis of dendritic connections with cone pedicles suggests multiple spectral types (Li et al., 2012). Signal transduction in the retina is highly conserved across vertebrates, with the connections of retinal neurons, overall layered organization, parallel ON- and OFFpathways, and excitatory glutamatergic inputs within the vertical transduction pathway (photoreceptors to bipolar cells to ganglion cells) observed in both zebrafish and humans. GABAergic, glycinergic, and dopaminergic cells are also present. A difference between zebrafish and mammals is seen in brain circuitry: the optic tectum, a midbrain structure, is responsible for all higher order visual processing in zebrafish. In humans, the midbrain LGN (lateral geniculate nucleus) receives and processes retinal inputs before projecting to visual cortex (V1) (Haynes et al., 2005). Though lacking V1, the zebrafish optic tectum is well developed and capable of cortical-level processing of visual stimuli, such as stimulus detection and orientation (Hunter et al., 2013), escape behaviors (Dunn et al., 2016), and prey capture (Muto and Kawakami, 2013). Thus, the overall similarities in anatomy and circuitry between zebrafish and humans, coupled with genetic techniques that can be easily applied, allows zebrafish to serve as a convenient and relevant model for testing the effects of endocrine disrupting compounds (EDCs) and for assessing deficits in visual physiology and behavior (Link and Collery, 2015).

\section{Estrogen Localization, Signaling, Receptor Types}

Classically, estrogen production occurs in the gonads and, to a lesser extent, the adrenal cortex, with release stimulated by the 


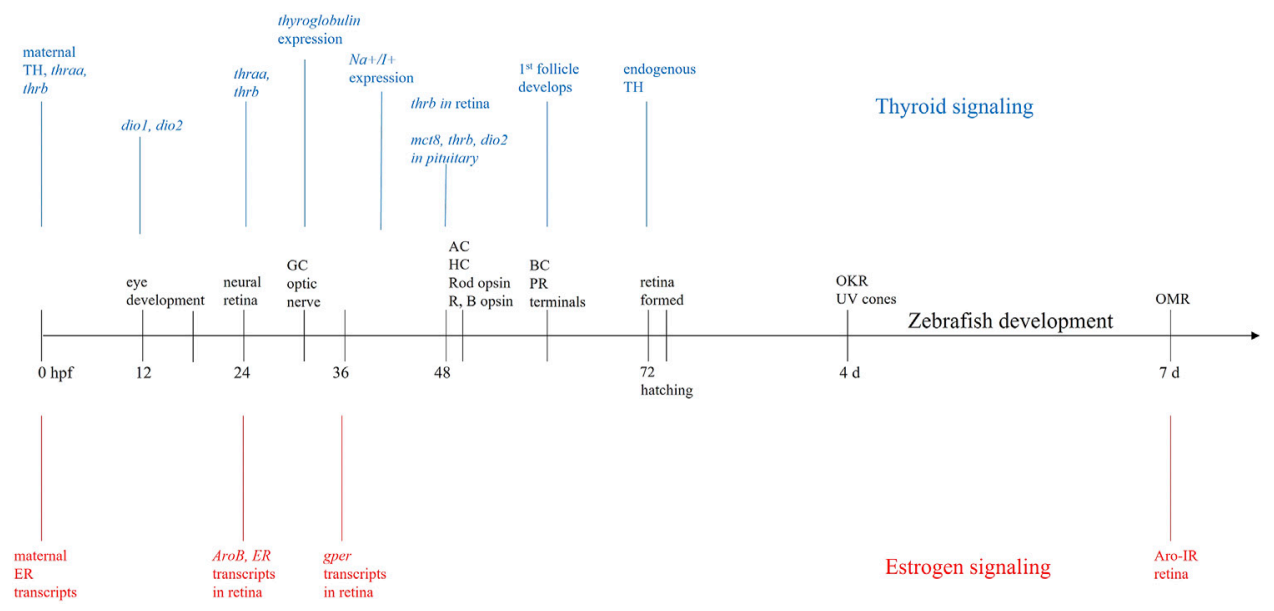

FIGURE 1 | Developmental timeline. Sequence of events in zebrafish eye and retinal development (black) beginning at fertilization (0 h postfertilization - hpf) and continuing until 7 days (days) postfertilization. During this time, maternally derived transcripts for estrogen receptors (ER-red) and maternally derived thyroid hormones (TH-blue) are present in yolk. At $24 \mathrm{hpf}$, when neural retina is developing, expression of ER and aromatase (AroB) are present in retina, and expression of the genes for both thyroid receptors (thraa, thrb) begins. Expression of G-protein coupled ER (gper) begins 36 hpf; at 48 hpf thrb is expressed in retina. At hatching (72 hpf), there is endogenous production of both $\mathrm{TH}$ and estrogen. The overlap and concurrent development of thyroid, estrogen, and retinal development, suggests these hormones are important for proper retinal/visual system development. $\mathrm{GC}=$ ganglion cell, $\mathrm{AC}=$ amacrine cell, $\mathrm{HC}=\mathrm{horizontal}$ cell, $\mathrm{R}=\mathrm{red}$ cone, $\mathrm{B}=\mathrm{blue}$ cone, $\mathrm{BC}=$ bipolar cell, $\mathrm{PR}=$ photoreceptor, $\mathrm{OKR}=$ optokinetic response, $\mathrm{OMR}=$ optomotor response.

hypothalamic-pituitary axis. Estradiol (17 $\beta$-estradiol or E2), the biologically relevant estrogen, is synthesized directly from the aromatization of testosterone by the enzyme aromatase (estrogen synthase), a product of the cyp19 gene. E2 is released from these glands directly into the bloodstream and, as it is best known for its roles in reproductive functions, is often referred to as a gonadal sex steroid (Menuet et al., 2005; Mccarthy, 2008). However, we have since learned that E2 synthesis and action are not restricted to reproductive tissues: E2 is locally produced via aromatase in a variety of non-reproductive tissues and throughout the nervous system (Lephart, 1996), inducing potent pleiotropic effects on central nervous system development, maturation, and function (Menuet et al., 2005).

For example, E2's effects extend to the visual system. The retina expresses aromatase, and estrogen receptors (ERs) are found in all retinal layers across vertebrate species (Gellinas and Callard, 1993; Callard et al., 2001; Cascio et al., 2007; Cascio et al., 2015), pointing to a conserved functional significance of local E2 synthesis and action. Indeed, E2 is neuroprotective in retina, preventing excitotoxic cell death and protecting against retinal degeneration in humans (Cascio et al., 2007). E2 also influences eye structure and function and the incidence of many ocular diseases (Cascio et al., 2007) and changes in E2 levels from aging or hormone therapies are associated with neurodegenerative retinal diseases and visual complications (Cascio et al., 2015).

Developmentally, ER transcripts in newly fertilized zebrafish embryos are maternally derived (Bardet et al., 2002; Lassiter et al., 2002; Tingaud-Sequeira et al., 2004) with endogenous transcription beginning around 24-48 hpf (Figure 1) (Bardet et al., 2002; Lassiter et al., 2002; Tingaud-Sequeira et al., 2004) and corresponding with the onset of aromatase mRNA expression
(Mouriec et al., 2009). By 7 dpf, aromatase can be detected in retina using immunocytochemistry (Le Page et al., 2011), suggesting local E2 expression.

\section{Aromatase in the Fish Brain}

Teleost fish have remarkably high levels of neural aromatase, a finding pioneered in longhorn sculpin (Callard et al., 1978) and goldfish (Pasmanik and Callard, 1988; Gellinas and Callard, 1993; Callard et al., 1995) and confirmed in other teleosts (Trimmers et al., 1987; Borg et al., 1989; Mayer et al., 1991; Gonzalez and Piferrer, 2002), including zebrafish (Kishida and Callard, 2001; Sawyer et al., 2006). It is estimated that teleost neural aromatase is about 100 to 1000 -fold greater when compared to mammals and birds (Pellegrini et al., 2005), and this high aromatase is thought to be involved in the regenerative abilities and plasticity of the teleost brain, optic nerve, and eye (Hamad et al., 2007). Furthermore, estrogens and estrogenic compounds upregulate the expression of developmental aromatase (Menuet et al., 2005; Sawyer et al., 2006), allowing neural aromatase in teleosts to serve as an indicator of estrogen signaling and modulation (Kishida et al., 2001).

Another unique feature of teleosts is that neural aromatase is exclusively expressed in a single and distinct cell type: radial glial cells (Menuet et al., 2005). These radial glial cells serve as progenitor cells that are essential in neurogenesis, where in mammals they act as embryonic neural stem cells that disappear shortly after birth (Schmidt and Scholpp, 2013). While these cell types are similarly important during zebrafish neurogenesis, they also persist into adulthood, continuing to express high levels of aromatase, proliferate, self-renew, and generate new neurons (Schmidt and Scholpp, 2013). Therefore, adult zebrafish seem to possess embryonic 
mammalian features in terms of neurogenesis, allowing them to serve as sensitive models for estrogen signaling and the effects of disruption (Le Page et al., 2011).

Zebrafish have two separate and distinct aromatase expressing genes that have subdivided expression domains. The cyp19a gene encodes aromatase A (AroA) which is primarily expressed in the gonads, whereas the cyp $19 b$ gene encodes aromatase B (AroB) which is expressed in neural tissues, including the brain and retina (Callard et al., 2001; Menuet et al., 2005). In the retina of goldfish, $A$ roB has been detected in horizontal, bipolar, and amacrine cells, and within ganglion cell projections to the brain from the optic nerve and tract (Callard et al., 1995). In support of a functional role of aromatase in the visual system, developmental exposure to known aromatase inhibitors causes thinning of retinal layers, delayed eye growth, and deficits in visually-guided behaviors (Hamad et al., 2007; Gould et al., 2017). Taken together, the localization of $A r o B$ in the retina and the anatomical and visual impacts from aromatase inhibition suggest a key role for E2 in the development and function of the visual system.

\section{Estrogen Receptors and Signaling}

Sequencing and phylogenetic analyses of human and zebrafish ERs reveal conserved functional motifs, high sequence homology, particularly in the DNA binding domain (C domain) (Bardet et al., 2002; Menuet et al., 2002) and near identical exon numbers and lengths (Lassiter et al., 2002). Further, human and teleost ERs exhibit similar binding characteristics (Thomas et al., 2010) and share the same intracellular signaling cascades (Thomas et al., 2010) and mechanisms of transcriptional activation (Klinge, 2001; Bardet et al., 2002). Thus, while we acknowledge that there may be species-specific differences in timing of events, the general signaling pathways and mechanisms of estrogen signaling are highly conserved across vertebrates (Klinge, 2001).

The actions of E2 are primarily mediated through two intracellular ERs, ER $\alpha$ and $\operatorname{ER} \beta$, that act as ligand-activated transcription factors to modulate estrogen target gene activity (Menuet et al., 2002). In the classical signaling pathway, intracellular ERs will form homo- or heterodimers upon E2 binding and translocate to the nucleus (Cascio et al., 2015). Once there, dimerized receptors bind to estrogen response elements (EREs) in promoter regions of DNA and recruit specific cofactors to alter gene expression (Belcher and Zsarnovszky, 2001; Mccarthy, 2008). E2 targets genes expressed in the retinal photoreceptor layer including grk7a and pde6ga (Hao et al., 2013). grk7a, or G-protein-coupled receptor kinase $7 \mathrm{a}$, is involved in visual perception and phototransduction; pde6ga is predicted to be involved the activation of MAPK activity (Vogalis et al., 2011; Thisse and Thisse, 2014). E2 increases the expression of these genes, thus, lower E2 levels would decrease expression, causing lowered photosensitivity or lower level of function overall in retina (Vogalis et al., 2011; Thisse and Thisse, 2014).

In addition to direct interaction with EREs, E2-activated nuclear ERs can also regulate transcription via an indirect genomic mechanism by associating with and influencing activity of transcription factors, including stimulating protein 1
(SP-1), activator protein 1 (AP-1), nuclear factor- $\kappa \mathrm{B}(\mathrm{NF}-\kappa \mathrm{B})$, and c-jun (Cui et al., 2013). Estrogen receptors can also participate in indirect "extranuclear signaling" through membrane-localized ERs in association with cytosolic kinases and growth factor signaling components to mediate rapid estrogenic effects (Levin, 2002). This extranuclear pathway can initiate multiple cytoplasmic signaling cascades that involve the downstream activation of MAPK/ERK, PI3K/AKT, and cAMP/ PKA, which can ultimately also lead to transcriptional changes (Cortez et al., 2013).

The ER $\alpha$ and ER $\beta$ isoforms have distinct functions (Mccarthy, 2009), developmental expression patterns, tissue distributions, genes, and affinities for E2 (Menuet et al., 2002). However, the presence of ER $\alpha$ and ER $\beta$ in retina has been observed in many vertebrate animals, including rats, bovines, humans, and teleosts (Kobayashi et al., 1998; Cascio et al., 2015). In zebrafish, there are two forms of $\operatorname{ER} \beta$ ( $\mathrm{zfER} \beta 1$ and $\mathrm{zfER} \beta 2$ ), which likely resulted from a duplication event in the teleost lineage (Menuet et al., 2002). In development, it is thought that ER $\beta 1$ is most highly expressed (Paige et al., 1999; Froehlicher et al., 2009). All three ERs (zfERa, zfER $\beta 1$, and zfER $\beta 2$ ) are detected in zebrafish eyes where they begin to be highly expressed 24-48hpf (Menuet et al., 2002; Tingaud-Sequeira et al., 2004; Mouriec et al., 2009) (Figure 1).

E2 can also bind to a membrane-bound G protein-coupled estrogen receptor (GPER) to elicit indirect rapid non-genomic signaling (Belcher and Zsarnovszky, 2001). GPER binding E2 activates cAMP through adenylyl cyclase, which causes downstream activation of MAPK and CREB pathways, promoting neuronal growth and survival (Shi et al., 2013; Roque and Baltazar, 2019). GPER activation also promotes the activity of kinases involved in neuronal protection, such as PI3K/ AKT (Roque and Baltazar, 2019).

Although the nervous system effects of E2 are largely attributed to classical ER genomic signaling, increasing evidence suggests that E2 mediated GPER activation is also involved (Luo and Liu, 2020). During zebrafish embryogenesis, GPER mRNA and protein shows a wide distribution throughout the central nervous system and can be detected from fertilization to $72 \mathrm{hpf}$, with high levels of expression occurring after $24 \mathrm{hpf}$ (Jayasinghe and Volz, 2011; Shi et al., 2013). gper has also been detected in the zebrafish eye at $36 \mathrm{hpf}$ and more recently in the retina, optic tract, and in nuclei of primary and secondary visual pathways of adult goldfish (Mangiamele et al., 2017). Further, genes involved in the MAPK/ERK pathway are present in zebrafish retina at various stages of development (Krens et al., 2006). GPER also plays a functional role as knockdowns induce apoptosis, decrease proliferation of brain cells, and cause abnormal development of sensory neurons (Shi et al., 2013). The presence of gper and downstream genes in the retina of embryonic zebrafish and the functional deficits of GPER knockdown suggest that E2 might rapidly modulate sensory processes via this non-genomic signaling pathway. Therefore, it appears that E2 exerts its effects in neurogenesis and neuroprotection using both long-term, transcriptional, and rapid, non-genomic mechanisms. 


\section{Thyroid Hormone Localization, Signaling, Receptor Types}

The adult thyroid gland releases two thyroid hormones (THs): tri-iodothyronine (T3) and tetra-iodothyronine, or thyroxine (T4). Both T3 and T4 require iodine, which is taken up from the blood stream and, after binding tyrosine, is bound to thyroglobulin for storage within thyroid follicles (Sellitti and Suzuki, 2014). Though a greater amount of T4 is released, it is converted to T3 after release and T3, with greater affinity for thyroid receptors, is the more active form. Conversion of T4 and/ or T3 occurs through the activity of three deiodinase enzymes: deiodinase type 2 (Dio2 or D2) converts T4 to T3, deiodinase type 3 (Dio3 or D3) inactivates T3 by converting it to reverse T3 (rT3) (Darras et al., 1999), and Dio1 (D1) performs both reactions, though it is considered the least efficient of the three (Bianco and Kim, 2006; Darras et al., 2011). All three deiodinases are present in zebrafish, and Dio2 is the major isoform producing useable T3 (Porazzi et al., 2009). Thyroid hormones impact all cells in the body, as they are important for growth and metabolic rate, and are involved in a variety of pathways during development (Silva et al., 2017).

In particular, THs are required for proper brain/CNS development (Boas et al., 2006; Darras et al., 1999; Howdeshell, 2002). In humans, initial TH levels are of maternal origin, with endogenous production occurring after 10-12 weeks gestation (Darras et al., 1999; Kohrle and Fradrich, 2021; Howdeshell, 2002). D3 activity in the placenta and fetus maintains constant fetal T3 levels (Patrick, 2009). Zebrafish embryos also have measurable levels of $\mathrm{TH}$ of maternal origin (Figure 1) (Silva et al., 2017; Gothie et al., 2019), resulting in stable whole body T3 and T4 levels until 60-72 hpf (Chang et al., 2012). At 72 hpf, endogenous TH synthesis begins (Porazzi et al., 2009; Darras et al., 2011; Gothie et al., 2019; Vancamp et al., 2019) causing internal $\mathrm{TH}$ levels to increase significantly, peaking at $10 \mathrm{dpf}$ (T3) and $21 \mathrm{dpf}$ (T4) (Chang et al,, 2012). A more recent study measuring $\mathrm{T} 3$ and $\mathrm{T} 4$ levels using fluorescent antibodies found hormone levels peak earlier, at $6 \mathrm{dpf}$, and then decrease (Rehberger et al., 2018). Prior to hatching, thyroglobulin expression begins at $32 \mathrm{hpf}$ and $\mathrm{Na}^{+} / \mathrm{I}^{+}$ symporter expression starts at $40 \mathrm{hpf}$ (Alt et al., 2006). The first thyroid follicle is evident $~ 55-60 \mathrm{hpf}$ (Alt et al., 2006) and follicles can be clearly seen at $72 \mathrm{hpf}$, which coincides with the onset of endogenous T4 production (Porazzi et al., 2009). Interestingly, this development and early functioning of the thyroid gland does not require thyroid-stimulating hormone (TSH) (Alt et al., 2006) and is, therefore, independent of the hypothalamic-pituitary axis (Vancamp et al., 2019).

Altering T3 levels by knockdown of deiodinases disrupts eye development by decreasing eye size, reducing cone numbers, and altering visually guided responses in zebrafish (Houbrechts et al., 2016). Sensitivity of the retina to TH levels remains throughout life. Indeed, external application of T3 from 2 to $4 \mathrm{dpf}$ alters cone opsin expression in exposed larvae, an effect also observed in juveniles exposed from 26 to $31 \mathrm{dpf}$ (Mackin et al., 2019).

\section{Thyroid Hormone Receptors and Signaling}

T3 converted from T4 is transported into target cells via a high affinity membrane transporter (such as monocarboxylate transporter 8 or mct8) (Arjona et al., 2011), where it binds to a thyroid hormone receptor (TR). Similar to ERs and other members of the nuclear receptor superfamily, TRs act as ligand-activated transcription factors that influence transcription of target genes (Flamant et al., 2017). TRs bound to T3 form a dimer, commonly a heterodimer (Flamant et al., 2017), with the retinoid X receptor (TR/RXR) (Li et al., 2002; Li et al., 2004) or the retinoic acid receptor (TR/RAR) (Lee and Privalsky, 2005) before binding to a thyroid response element (TRE) on DNA to alter target gene transcription (Lazar et al., 1991). An interesting aspect of thyroid hormone signaling is that both RXR and RAR can also bind their natural ligand, retinoic acid, when bound to TR (Li et al., 2002; Li et al., 2004; Bohnsack and Kahana, 2013) and interactions between thyroid and retinoic acid signaling have been reported (Essner et al., 1997). In addition to this canonical genomic pathway, T3 can interact with plasma membrane integrin av $\beta 3$ to initiate rapid intracellular signaling cascades involved in neuroprotection, growth, and apoptotic regulation, including MAPK (ERK1/2) and PI3K/AKT (Flamant et al., 2017).

In mammals there are 2 TR genes: TR $\alpha$ and TR $\beta$ (Bernal et al., 2003; Bernal, 2005). Zebrafish also have TR $\alpha$ and $\operatorname{TR} \beta$ that respond to $\mathrm{TH}$ (Porazzi et al., 2009). In mammals, the $\mathrm{TH}$ receptor genes code for various protein products with TRa1, $\operatorname{TR} \beta 1, \operatorname{TR} \beta 2$, and $\operatorname{TR} \beta 3$ able to bind to both T3 and to DNA (Bernal et al., 2003; Bernal, 2005). In zebrafish, one gene encodes $\operatorname{TR} \beta$ (thrb), but two genes encode TRa (thraa and thrab) (Liu et al., 2000; Porazzi et al., 2009; Darras et al., 2011; Marelli et al., 2016), with all receptor isoforms expressed in retina. The thraa gene forms two proteins: TRaA-1 and TRaA1-2 (Porazzi et al., 2009; Darras et al., 2011), with TRaA-1 corresponding to mammalian TRal (Darras et al., 2011). Thrb encodes three isoforms: $\quad$ TRR $\beta 1 \mathrm{~s}$ (short), zTR $\beta 1 \mathrm{~L}$ (long) and zTR $\beta 2$ (Vancamp et al., 2019). All receptors bind T3 and are intracellular (Marelli et al., 2016).

During early embryogenesis, both thraa and thrb are expressed in zebrafish embryos (Liu et al., 2000; Porazzi et al., 2009; Vancamp et al., 2019), peaking at $18 \mathrm{hpf}$, then decreasing to undetectable levels until $24 \mathrm{hpf}$ when expression again increases (Marelli et al., 2016). At $48 \mathrm{hpf}$, thrb is detectable in retina and it is still expressed in the eye and muscles of adult zebrafish (Marelli et al., 2016). Expression of mct8 (Vancamp et al., 2019) and Dio2 are also found in developing retina (Bohnsack and Kahana, 2013). Thus, though endogenous $\mathrm{TH}$ production does not begin until hatching, gene expression and/or development of thyroid signaling components are present much earlier, indicating high embryonic $\mathrm{TH}$ levels may drive expression of pathway components (Liu et al., 2000).

\section{Role of Estrogen in Visual Function}

As noted above, development of the retina/visual system and estrogenic signaling occur simultaneously (Figure 1), suggesting an interaction between these two processes. Indeed, many animal 
studies have suggested that proper estrogenic signaling is critical for neurogenesis of the visual system: developmental manipulation of estradiol signaling or synthesis causes abnormal eye growth (Hamad et al., 2007; Hano et al., 2007), deficits in visually guided behaviors (Lovato et al., 2017; CrowleyPerry et al., 2021), and thinning and apoptosis in the retina (Dong et al., 2006; Hamad et al., 2007). Much of this research uses EDCs to determine the role of $\mathrm{E} 2$ in the visual system. Here, we discuss the visual system effects of EDCs acting as E2 agonists-BPA and EE2-and E2 antagonists-TBT and 4-OH-A.

Bisphenol-A (BPA) is a familiar, ubiquitous chemical (Arase et al., 2011) used primarily in the manufacture of polycarbonate and epoxy resins (Chapin et al., 2008) and it is present in plastic water bottles, food containers, and dental sealants. BPA levels in humans are measurable and significant (Ben-Jonathan and Steinmetz, 1998) and occur in $\sim 93 \%$ of the population (Group, 2013). BPA is effective at extremely low (nM) doses (Ben-Jonathan and Steinmetz, 1998) which correspond to the median value reported in US streams (Kolpin et al., 2002). BPA levels can be measured in human tissues and fluids (Chapin et al., 2008; Vandenberg et al., 2010; Lakind and Naiman, 2011) and, significantly, BPA is able to cross the placenta (Takahashi and Oishi, 2000; Chapin et al., 2008; Vandenberg et al., 2009) resulting in measurable fetal levels (Schonfelder et al., 2002; Chapin et al., 2008). There are no reports documenting developmental effects of BPA on humans (Chapin et al., 2008); however, in utero exposure (Chapin et al., 2008) causes a variety of behavioral deficits (Farabollini et al., 1999; Jasarevic et al., 2011; Kim et al., 2011; Wolstenholme et al., 2012) and is linked to childhood asthma (Nakajima et al., 2012) in rodents.

Our lab, and others, have reported the deleterious effects of exposure to BPA on the visual system. BPA targets neuroendocrine systems as a weak E2 agonist that binds and activates both ERs (Chung et al., 2011; Cano-Nicolau et al., 2016) and GPER (Thomas and Dong, 2006). BPA is extremely effective at low concentrations (Ben-Jonathan and Steinmetz, 1998), with exposure causing hyperactivity (Saili et al., 2012; Kinch et al., 2015; Weber et al., 2015), reduced midbrain size (Tse et al., 2013), and reduced outgrowth of motor neurons (Wang et al., 2013) in zebrafish. Because ER and aromatase regulation are estrogendependent, BPA causes dramatic overexpression of aromatase (Chung et al., 2011; Cano-Nicolau et al., 2016) and ER mRNA (Kishida et al., 2001), resulting in abnormally high estrogen signaling with likely adverse effects on nervous system development and function (Cano-Nicolau et al., 2016). For example, acute (24-48 h) BPA exposure in embryonic zebrafish causes defects in otolith formation (Gibert et al., 2011) and decreases in hair cell survival and regeneration (Hayashi et al., 2015), demonstrating that short-term exposure to BPA can have deleterious effects on sensory systems. Specific to the visual system, a chronic 120-day exposure in embryonic zebrafish (2 hpf) to BPS, a BPA analogue with similar estrogenic actions (Qiu et al., 2016), decreased tracking ability and the thickness of the ganglion cell layer and retina, and induced irregular arrangement of photoreceptor cells (Liu et al., 2017). Lastly, acute ( $24 \mathrm{~h})$ exposure to BPA in larval zebrafish aged $72 \mathrm{hpf}$ and $7 \mathrm{dpf}$ resulted in changes in eye diameter and visually guided behaviors that were evident 1-2 weeks after removal from treatment (Crowley-Perry et al., 2021). These findings suggest that short- and long-term exposure to BPA can evoke both immediate and sustained effects on sensory systems, including the visual system.

Ethinyl-estradiol (EE2) is another estrogen receptor agonist that has been tested in zebrafish. EE2 is a synthetic derivative of endogenous E2 and, due to its wide use as a constituent in oral contraceptives, reaches aquatic environments through wastewater effluents (Vilela et al., 2021); agricultural and aquaculture runoff are other sources (Tang et al., 2021). EE2 concentration in surface waters varies, ranging up to $62 \mathrm{ng} / \mathrm{L}$ (Versonnen and Janssen, 2004), and it is consistently identified worldwide make it a serious environmental contaminant (Tang et al., 2021). EE2 exhibits higher potency and ER binding affinity than E2 (Aten and Eisenfeld, 1982; Denny et al., 2009), thus eliciting estrogenic effects at and below levels detected in the environment. There are no available epidemiological reports of EE2 and its effects on human sensory systems. However, EE2 binds to teleost and mammalian ERs (Aten and Eisenfeld, 1982), and environmentally relevant levels adversely affect fish (Nikoleris et al., 2016; Tang et al., 2021; Ramirez-Montero et al., 2022).

Embryonic zebrafish at 8-10 dpf exposed to picomolar concentrations of EE2 (10-1,000 p.m.) between 1 and $7 \mathrm{dpf}$ of development have significantly inhibited axonal nerve and hair cell regeneration, suggesting direct impairments to nervous and sensory system development (Nasri et al., 2021). Similar 7-day EE2 exposures using $\mathrm{pM}$ to low $\mathrm{nM}$ concentrations caused significant overexpression of brain AroB and ERa/ $\beta$ transcripts in juvenile Atlantic salmon (Lyssimachou et al., 2006) and $7 \mathrm{dpf}$ zebrafish (Cano-Nicolau et al., 2016; Nasri et al., 2021). Specific EE2 effects have also been observed in retina, where a 32-day exposure to low nanomolar concentrations $(4-100 \mathrm{ng} / \mathrm{L})$ decreased the outer and inner plexiform layers and total retinal thickness of minnows assessed at 28 days post-hatch (Alcaraz et al., 2021), an effect likely attributed to disrupted and/or heightened estrogen signaling.

Tributyltin (TBT) is an EDC that targets estrogenic pathways, but with opposite effects to BPA and EE2. TBT is an organotin compound used commonly as a biocide in antifouling paints applied to boats and marine structures and was historically found at high concentrations in aquatic environments (Mcallister and Kime, 2003). Though the International Maritime Organization banned the use of TBT in anti-fouling paints in 2008 (Showalter and Savarese, 2004; Gipperth, 2009; IMO, 2019), which lead to reduced environmental levels (Liang et al., 2017) and wildlife recovery (Jones and Ross, 2018), recent reports identify spikes in TBT levels $(\mu \mathrm{g} / \mathrm{g})$ in coastal areas off of Latin America, Norway, and Panama (Batista-Andrade et al., 2018; Schoyen et al., 2019; Castro et al., 2021) and TBT-based paint is still sold (Uc-Peraza et al., 2022), suggesting continued exposure. TBT is not readily biodegradable (Mcallister and Kime, 2003) and, once ingested, bioaccumulates and crosses the blood brain barrier, concentrating in areas of the brain that receive sensory inputs (Roulea et al., 2003). 
TBT exposure in humans is not well studied, though exposure is thought to occur through consumption of contaminated fish or shellfish (Chien et al., 2002; Antizar-Ladislao, 2008). Such dietary intake of TBT has been measured worldwide and TBT is reported to inhibit placental aromatase (reviewed in Antizar-Ladislao, 2008), suggesting an impact on development.

TBT exposure causes a range of adverse effects, including increasing oxidative stress, triggering an immune response, reducing neurotransmitter synthesis/levels, increasing lipid accumulation, and altering liver function (Zhang CN. et al., 2017; Zhang J. et al., 2017; Ortiz-Villanueva et al., 2018; Barbosa et al., 2019; Li and Li, 2021; Shi et al., 2021). Relevant to this review is that TBT is also a known aromatase inhibitor that prevents the synthesis of E2 and decreases AroB expression in zebrafish brain (Lyssimachou et al., 2006). Plasma levels of testosterone are correspondingly increased, leading to deleterious effects on the reproductive system and population sex ratios. High levels of imposex in gastropod mollusks (Schoyen et al., 2019) and masculinization in fish (Mcallister and Kime, 2003; Santos et al., 2006; Mcginnis and Crivello, 2011) occur after TBT exposure. Within the visual system, embryonic fish ( $<8 \mathrm{hpf})$ transiently exposed to TBT exhibit abnormal eye growth (Hano et al., 2007) and apoptosis of retinal neurons (Dong et al., 2006). Degeneration and abnormal ordering of retinal layers has also been observed in larvae exposed to TBT for 10 days (Fent and Meier, 1992). Additionally, transient 24-h exposure to TBT during development alters visually guided optomotor responses (OMRs) measured 1-week after removal from treatment (Bernardo and Connaughton, 2022). Effects were age-dependent, with reduced OMRs occurring if TBT exposure occurred at $72 \mathrm{hpf}$ or $7 \mathrm{dpf}$; reduced eye diameters were also observed when exposure occurred at $7 \mathrm{dpf}$.

Exposure studies using the pharmaceutical EDC 4-hydroxyandrostendione (4-OH-A or Formestane), another potent aromatase inhibitor, provide further support for the role of E2 in visual system development. A 3-day application of 4-OH-A to $48 \mathrm{hpf}$ zebrafish prevented expression of normal sensory motor behaviors, including swimming movement, tactile response, fin movement, and eye movement (Nelson et al., 2008). Coapplication with E2 at a concentration determined to be optimal for the transcriptional activation of ERs (Menuet et al., 2002) and upregulation of AroB mRNA (Kishida et al., 2001) rescued all sensory responses (Nelson et al., 2008), pointing to a key functional role of E2 signaling via ERs in sensory system development. Additionally, acute, 24-h exposure to 4-OH-A significantly decreased eye diameter in $7 \mathrm{dpf}$ zebrafish (Gould et al., 2019). We also observed that the visual system effects of 4 $\mathrm{OH}-\mathrm{A}$ persist into adulthood, as a 24 -h exposure at $24 \mathrm{hpf}, 72 \mathrm{hpf}$, and $7 \mathrm{dpf}$ larval zebrafish resulted in significantly decreased visually guided optomotor responses in adults (3-4 months removed from treatment) (Gould et al., 2017), suggesting that even a brief disruption to estrogen signaling during development can have effects on maturation and long-term function. Taken together, these studies indicate that modulating E2 signaling via EDCs imposes both immediate and long-term effects on visual system development and function at a wide range of concentrations, developmental timepoints, and exposure durations.

\section{Role of Thyroid Hormones in Visual Function}

Similar to estrogenic signaling, thyroid hormone signaling also coincides with retinal development (Figure 1). However, compared to E2, THs have a more direct involvement in retinal neurogenesis as they are required for neuronal maturation and cell fate of cone photoreceptors (Harpavat and Cepko, 2003; Roberts et al., 2006). In particular, TH binding to TR $\beta 2$ determines correct expression of cone opsins in both zebrafish (Harpavat and Cepko, 2003; Suzuki et al., 2013; Volkov et al., 2020) and rodents (Roberts et al., 2006). During development, zebrafish cones can express one of seven different opsins: lws1 (R1) or lws2 (R2) (red cones); rh2-1/rh2-2 (G1) or rh2-3 (G3) (green cones); sws2 (B1) or B2 (blue cones); sws1 (UV cones) (Takechi and Kawamura, 2005; Endeman et al., 2013; Nelson et al., 2019). $\operatorname{tr} \beta 2$ expression is specifically required for expression of the red cone opsin (Suzuki et al., 2013) lws1 (Suzuki et al., 2013; Mackin et al., 2019; Volkov et al., 2020). Consequently, knockdown of $\operatorname{tr} \beta 2$ reduces the number of red cones (Suzuki et al., 2013); zebrafish thrb mutants, as larvae or adults, have an anatomical loss of red cones (Volkov et al., 2020), which is associated with reduced response to red light and a loss of red cone inputs to the ERG (Deveau et al., 2020). Exposing zebrafish larvae to T3 from 2 to $4 \mathrm{dpf}$ increased expression and distribution of lws1 (Mackin et al., 2019), consistent with effects in TR $\beta 2$ mutants. Interestingly, juveniles exposed to T4 from 26-31 dpf did not display a difference in lws1 expression (Mackin et al., 2019), though lws 2 was altered. However, TH application upregulated $c y p 27 c 1$ in zebrafish juveniles (Mackin et al., 2019; Volkov et al., 2020). cyp27c1 codes for the enzyme that converts vitamin A1 (the chromophore bound to opsin in zebrafish) to vitamin A2 in the retinal pigment epithelium (Allison et al., 2004; Enright et al., 2015; Volkov et al., 2020), consistent with a THinduced shift toward longer wavelength sensitivity (Mackin et al., 2019; Volkov et al., 2020).

Though a major effect of $\operatorname{tr} \beta 2$ expression is found in red cones, other cone types are also affected by changes in expression of this TR. For example, reductions in $\operatorname{tr} \beta 2$ leads to an increase in the number of cones expressing UV opsin in zebrafish (Suzuki et al., 2013; Volkov et al., 2020), similar to the increase in S-cone number observed in TR $\beta 2$-null mice (Roberts et al., 2006), suggesting $\operatorname{tr} \beta 2$, and $\mathrm{TH}$ signaling, determines L-cone vs. UVcone fate (Suzuki et al., 2013). Exposing $\operatorname{tr} \beta 2$ mutant zebrafish larvae (2-4 dpf) to T3 caused a dose dependent increase in rh2-2 and rh2-3 expression (Mackin et al., 2019) in green cones, which was observed physiologically as reduced green sensitivity and a shift to a longer peak wavelength in photopic ERG recordings (Deveau et al., 2020), another example of a TH-induced shift to longer wavelength sensitivity. These results in zebrafish agree with those from human retinal organoid cultures, which show that $\mathrm{TH}$ binding to TR $\beta 2$ is required for $\mathrm{L} / \mathrm{M}$ cone development (Eldred et al., 2018). 
The thyroid axis is very sensitive to environmental chemicals. Many identified contaminants are able to affect this system and all levels are sensitive to disruption (Howdeshell, 2002; Boas et al., 2006; Patrick, 2009; Kohrle and Fradrich, 2021). Clinically, and experimentally, two EDCs are used to block TH synthesis: methimazole (MMI) or propylthiouracil (PTU). Both compounds are used as a treatment for hyperthyroidism (Yu et al., 2020) as they reduce the activity of thyroid peroxidase, the enzyme that catalyzes binding of iodine to tyrosine (Ohtaki et al., 1996); PTU also prevents formation of T4 from thyroglobulin (Bohnsack and Kahana, 2013). Song et al. (2017) performed a meta-analysis to assess the risk of congenital abnormalities in children born to mothers prescribed MMI vs. PTU during pregnancy. They conclude that MMI exposure resulted in a greater risk of congenital malformations, compared to mothers taking PTU (Song et al., 2017). Furter, disruption of or reduced $\mathrm{TH}$ signaling during pregnancy causes abnormal brain development and/or cognitive impairments (Patrick, 2009; Noyes et al., 2019). These deleterious effects can extend to "brain derivatives" that include retina, cochlea, and pacemaker cells (Howdeshell, 2002).

Exposing zebrafish embryos to $0.3 \mathrm{mM}$ MMI between 60 and $72 \mathrm{hpf}$ causes smaller eye diameters at $65 \mathrm{hpf}$ which corresponded to a thinner GCL and IPL in treated retinas (Reider and Connaughton, 2014). Other neuronal, pharyngeal, and esophageal anomalies were also reported in zebrafish embryonically exposed to MMI (Komoike et al., 2013). These latter effects are similar to anomalies resulting from in utero exposure in humans (Komoike et al., 2013). MMI also reduces $\mathrm{TH}$ levels in adult rodents and reduces expression of Dio3 and Dio2 (Glaschke et al., 2011), suggesting not only reduced overall synthesis of $\mathrm{TH}$, but a reduced ability to convert/activate circulating $\mathrm{TH}$.

Exposure to PTU from 0 to $5 \mathrm{dpf}$ reduced eye size in zebrafish larvae and alters optokinetic responses (Baumann et al., 2016; Gothie et al., 2019); effects correlated with PTU-induced downregulation of TR expression (Baumann et al., 2016). Subsequent microarray analysis revealed PTU exposure caused downregulation of phototransduction-related genes coding for opsins, phosphodiesterase, and arrestin (Baumann et al., 2019). In fact, of the genes involved in sensory perception, expression of $>90 \%$ were found to be downregulated by PTU. The number of downregulated genes remained high when measured after a 3-day removal from treatment, though the levels of downregulation were less (Baumann et al., 2019), suggesting differential sensitivity to specific genes and long-term impacts of exposure.

TBBPA (tetrabromobisphenol-A) has also been used to examine $\mathrm{TH}$ signaling. TBBPA can bind to TR as either an agonist or antagonist, depending on the concentration used. TBBPA exposure reduced eye size and altered OKR in zebrafish larvae exposed from 0 to $5 \mathrm{dpf}$ (Baumann et al., 2016; Gothie et al., 2019). The effect of TBBPA exposure on expression of specific genes was variable (Baumann et al., 2016), consistent with agonistic and/or antagonistic effects of this compound. Indeed, though opsin expression was upregulated after a 5-day exposure to TBBPA (from 0 to $5 \mathrm{dpf}$ ), overall TBBPA exposure caused more general effects than PTU
(Baumann et al., 2019). However, compared to PTU-induced downregulation of genes involved in sensory perception, $>80 \%$ were upregulated by TBBPA. Following 3 days of recovery/ removal from treatment, opsin gene expression was still upregulated and detectable in TBBPA treated fish (Baumann et al., 2019).

\section{Summarizing E2 and TH Effects Identifies Crosstalk Between Estrogenic and Thyroidogenic Pathways}

E2 and TH-based signaling pathways have many similarities (Figure 2). These similarities, though highlighted in zebrafish, are highly conserved across vertebrates. Both hormones are released from glands that receive stimulation through the hypothalamic-pituitary axis and both cross the plasma membrane of cells, bind intracellular receptors, initiate overlapping cytoplasmic signaling cascades, and interact with hormone response elements (HREs) to influence gene expression. Significantly, the half-sites of thyroid response elements (TREs) and estrogen response elements (EREs) exhibit striking sequence similarities in various promoters (Glass et al., 1988; Scott et al., 1997; Vasudevan et al., 2002). TRs have been shown to bind the consensus ERE with high affinity, preventing ERa-ERE interaction and consequently ERa-mediated transcription (Glass et al., 1988; Vasudevan et al., 2001; Vasudevan et al., 2002). There is evidence that ERs can also take part in this competition by binding TREs to suppress the effect of T3 on target promoters (Yarwood et al., 1993) and mediate strong estrogen-dependent activation of transcription (Graupner et al., 1991). Therefore, it appears that competition between ERs and TRs can lead to antagonizing effects.

One of the significant published reports related to cross talk between E2 and TH signaling relates to the shared sensitivity to BPA. As noted above, BPA is a weak estrogen agonist; however, it is also an antagonist of TR that prevents binding of T3 (Moriyama et al., 2002; Zoeller et al., 2005; Jung et al., 2007; Heimeier et al., 2009), thereby inhibiting negative feedback by TH and increasing serum T4 levels (Zoeller et al., 2005). BPA is a better antagonist for TR $\beta$ than TRa (Zoeller et al., 2005). Importantly, binding of $\mathrm{BPA}$ to $\mathrm{TH}$ receptors occurs at relatively high $(>10 \mu \mathrm{M}) \mathrm{BPA}$ doses (Moriyama et al., 2002; Zoeller et al., 2005; Vandenberg et al., 2009). Low doses of BPA are reported to increase androgen receptor mRNA expression (Richter et al., 2007) but not to have anti-androgenic activity in vivo (Chapin et al., 2008). These interactions between $\mathrm{TH}$ and E2 signaling pathways, coupled to maternally derived $T H$ and $E R$ transcripts, their localization in the same tissues and the ability of those tissues to locally regulate hormonal actions, suggests $\mathrm{TH}$ and E2 signaling could mediate specific developmental events, such as retinal development.

Both hormones are present in the developing retina and synthesized locally within retinal tissue. In teleosts, the localization of neural aromatase, ERs, and GPER within embryonic and adult retina, and the functional deficits observed upon experimental estrogenic modulation, points to a key role of E2 in the visual system. Further, the importance of $\mathrm{TR} \beta 2$ in cone photoreceptors and the strong early presence of 


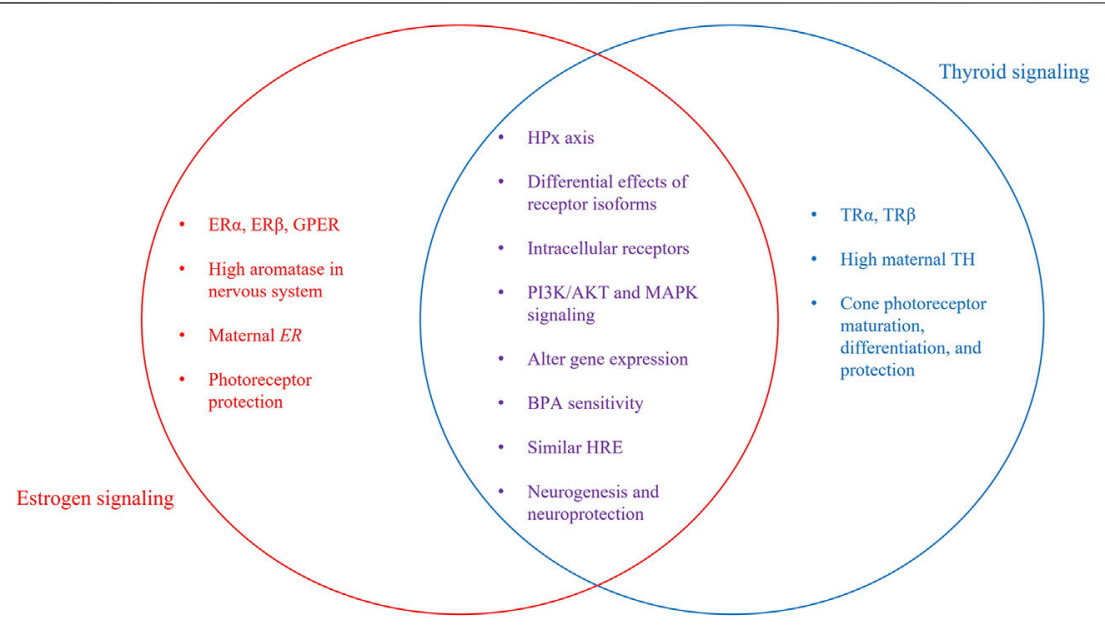

FIGURE 2 | Independent and interactive pathway components. Venn Diagram showing individual and interactive aspects of estrogen and thyroid signaling. Shared characteristics between both signaling pathways include the involvement of the hypothalamus-pituitary axis, intracellular receptors, some intracellular signaling molecules, and effects on gene transcription. Both E2 and TH are required for neurogenesis, including development of the visual system. Photoreceptors are the retinal cell type most sensitive, as TH is required for correct development and organization of cones. E2 is neuroprotective, preventing cell loss due to light-damage or disease.

maternal TH suggest a role for $\mathrm{TH}$ in the visual system. At $24 \mathrm{hpf}$, when the retina begins to develop, both thraa and thrb are expressed and $\mathrm{TH}$ levels are high due to maternally derived hormones in yolk. $A r o B$ and $E R$ transcripts are detectable in retina at $24 \mathrm{hpf}$ (Mouriec et al., 2009). Over the next $\sim 12 \mathrm{~h}$, thyroglobulin (Alt et al., 2006) and gper (Mangiamele et al., 2017) expression is detected and the optic nerve leaves the eye (Steurmer et al., 1988). By 48-50 hpf, amacrine and horizontal cells in the INL appear, opsin expression begins, and thrb expression is seen in retina. When hatching occurs, retina and thyroid are fully functional and E2 signaling is functional.

Though thyroid and estrogen signaling have been examined for decades, there are still effects/mechanisms of these hormones that are poorly understood. Further their interaction(s) and influence(s) on each other is clearly complex and even less understood. However, considering the consequences of $\mathrm{TH}$ and $\mathrm{E} 2$ dysregulation, crosstalk in

\section{REFERENCES}

Alcaraz, A. J. G., Potěšil, D., Mikulášek, K., Green, D., Park, B., Burbridge, C., et al. (2021). Development of a Comprehensive Toxicity Pathway Model for 17aEthinylestradiol in Early Life Stage Fathead Minnows (Pimephales promelas). Environ. Sci. Technol. 55, 5024-5036. doi:10.1021/acs.est.0c05942

Allison, W. T., Barthel, L. K., Skebo, K. M., Takechi, M., Kawamura, S., and Raymond, P. A. (2010). Ontogeny of Cone Photoreceptor Mosaics in Zebrafish. J. Comp. Neurol. 518, 4182-4195. doi:10.1002/cne.22447

Allison, W. T., Haimberger, T. J., Hawryshyn, C. W., and Temple, S. E. (2004). Visual Pigment Composition in Zebrafish: Evidence for a RhodopsinPorphyropsin Interchange System. Vis. Neurosci. 21, 945-952. doi:10.1017/ S0952523804216145

Alt, B., Reibe, S., Feitosa, N. M., Elsalini, O. A., Wendl, T., and Rohr, K. B. (2006). Analysis of Origin and Growth of the Thyroid Gland in Zebrafish. Dev. Dyn. 235, 1872-1883. doi:10.1002/dvdy.20831 signaling, and developmental co-localization of receptors presented in this review, it is likely that these hormones work synergistically in the development, maturation, and function of the visual system. It is also likely that other sensory systems are impacted in a similar manner and future work should address these questions.

\section{AUTHOR CONTRIBUTIONS}

All authors listed have made a substantial, direct, and intellectual contribution to the work and approved it for publication.

\section{FUNDING}

This project was funded by NIH Grant R15EY029866-01 (to VC).

Antizar-Ladislao, B. (2008). Environmental Levels, Toxicity and Human Exposure to Tributyltin (TBT)-contaminated marine Environment. A Review. b_antizar@hotmail.Com. Environ. Int. 34, 292-308. doi:10.1016/j.envint. 2007.09.005

Arase, S., Ishii, K., Igarashi, K., Aisaki, K., Yoshio, Y., Matsushima, A., et al. (2011). Endocrine Disrupter Bisphenol A Increases In Situ Estrogen Production in the Mouse Urogenital Sinus. Biol. Reprod. 84, 734-742. doi:10.1095/biolreprod.110. 087502

Arjona, F. J., De Vrieze, E., Visser, T. J., Flik, G., and Klaren, P. H. (2011). Identification and Functional Characterization of Zebrafish Solute Carrier Slc16a2 (Mct8) as a Thyroid Hormone Membrane Transporter. Endocrinology 152, 5065-5073. doi:10.1210/en.2011-1166

Aten, R. F., and Eisenfeld, A. J. (1982). Estradiol Is Less Potent Than Ethinyl Estradiol for In Vivo Translocation of the Mammalian Liver Estrogen Receptor to the Nucleus. Endocrinology 111, 1292-1298. doi:10.1210/endo-111-4-1292

Bahadori, R., Huber, M., Rinner, O., Seeliger, M. W., Geiger-Rudolph, S., Geisler, R., et al. (2003). Retinal Function and Morphology in Two Zebrafish Models of 
Oculo-Renal Syndromes. Eur. J. Neurosci. 18, 1377-1386. doi:10.1046/j.14609568.2003.02863.x

Barbosa, M. A. G., Capela, R., Rodolfo, J., Fonseca, E., Montes, R., André, A., et al. (2019). Linking Chemical Exposure to Lipid Homeostasis: A Municipal Waste Water Treatment Plant Influent Is Obesogenic for Zebrafish Larvae. Ecotoxicol Environ. Saf. 182, 109406. doi:10.1016/j.ecoenv.2019.109406

Bardet, P. L., Horard, B., Robinson-Rechavi, M., Laudet, V., and Vanacker, J. M. (2002). Characterization of Oestrogen Receptors in Zebrafish (Danio rerio). J. Mol. Endocrinol. 28, 153-163. doi:10.1677/jme.0.0280153

Batista-Andrade, J. A., Caldas, S. S., Batista, R. M., Castro, I. B., Fillmann, G., and Primel, E. G. (2018). From TBT to Booster Biocides: Levels and Impacts of Antifouling along Coastal Areas of Panama. Environ. Pollut. 234, 243-252. doi:10.1016/j.envpol.2017.11.063

Baumann, L., Ros, A., Rehberger, K., Neuhauss, S. C., and Segner, H. (2016). Thyroid Disruption in Zebrafish (Danio rerio) Larvae: Different Molecular Response Patterns lead to Impaired Eye Development and Visual Functions. Aquat. Toxicol. 172, 44-55. doi:10.1016/j.aquatox.2015.12.015

Baumann, L., Segner, H., Ros, A., Knapen, D., and Vergauwen, L. (2019). Thyroid Hormone Disruptors Interfere with Molecular Pathways of Eye Development and Function in Zebrafish. Int. J. Mol. Sci. 20. doi:10.3390/ijms20071543

Belcher, S. M., and Zsarnovszky, A. (2001). Estrogenic Actions in the Brain: Estrogen, Phytoestrogens, and Rapid Intracellular Signaling Mechanisms. J. Pharmacol. Exp. Ther. 299, 408-414.

Ben-Jonathan, N., and Steinmetz, R. (1998). Xenoestrogens: The Emerging Story of Bisphenol A. Trends Endocrinol. Metab. 9, 124-128. doi:10.1016/s10432760(98)00029-0

Bernal, J., Guadaño-Ferraz, A., and Morte, B. (2003). Perspectives in the Study of Thyroid Hormone Action on Brain Development and Function. Thyroid 13, 1005-1012. doi:10.1089/105072503770867174

Bernal, J. (2005). Thyroid Hormones and Brain Development. Vitam Horm. 71, 95-122. doi:10.1016/S0083-6729(05)71004-9

Bernardo, R. C., and Connaughton, V. P. (2022). Transient Developmental Exposure to Tributyltin Reduces Optomotor Responses in Larval Zebrafish (Danio rerio). Neurotoxicol Teratol 89, 107055. doi:10.1016/j.ntt.2021.107055

Bianco, A. C., and Kim, B. W. (2006). Deiodinases: Implications of the Local Control of Thyroid Hormone Action. J. Clin. Invest. 116, 2571-2579. doi:10. 1172/JCI29812

Bibliowicz, J., Tittle, R. K., and Gross, J. M. (2012). Toward a Better Understanding of Human Eye Disease Insights from the Zebrafish, Danio rerio. Prog. Mol. Biol. Transl Sci. 100, 287-330. doi:10.1016/B9780-12-384878-9.00007-8

Bilotta, J., Saszik, S., Givin, C. M., Hardesty, H. R., and Sutherland, S. E. (2002). Effects of Embryonic Exposure to Ethanol on Zebrafish Visual Function. Neurotoxicol Teratol 24, 759-766. doi:10.1016/s0892-0362(02)00319-7

Boas, M., Feldt-Rasmussen, U., Skakkebaek, N. E., and Main, K. M. (2006). Environmental Chemicals and Thyroid Function. Eur. J. Endocrinol. 154, 599-611. doi:10.1530/eje.1.02128

Bohnsack, B. L., and Kahana, A. (2013). Thyroid Hormone and Retinoic Acid Interact to Regulate Zebrafish Craniofacial Neural Crest Development. Dev. Biol. 373, 300-309. doi:10.1016/j.ydbio.2012.11.005

Borg, B., Andersson, E., Mayer, I., and Lambert, J. G. (1989). Aromatase Activity in the Brain of the Three-Spined Stickleback, Gasterosteus aculeatus. III. Effects of Castration under Different Conditions and of Replacement with Different Androgens. Exp. Biol. 48, 149-152.

Brockerhoff, S. E., Hurley, J. B., Niemi, G. A., and Dowling, J. E. (1997). A New Form of Inherited Red-Blindness Identified in Zebrafish. J. Neurosci. 17, 4236-4242. doi:10.1523/jneurosci.17-11-04236.1997

Brockerhoff, S. E. (2006). Measuring the Optokinetic Response of Zebrafish Larvae. Nat. Protoc. 1, 2448-2451. doi:10.1038/nprot.2006.255

Callard, G. V., Kruger, A., and Betka, M. (1995). The Goldfish as a Model for Studying Neuroestrogen Synthesis, Localization, and Action in the Brain and Visual System. Environ. Health Perspect. 103 (Suppl. 7), 51-57. doi:10.1289/ ehp.95103s 751

Callard, G. V., Petro, Z., and Ryan, K. J. (1978). Phylogenetic Distribution of Aromatase and Other Androgen-Converting Enzymes in the Central Nervous System. Endocrinology 103, 2283-2290. doi:10.1210/endo-103-6-2283

Callard, G. V., Tchoudakova, A. V., Kishida, M., and Wood, E. (2001). Differential Tissue Distribution, Developmental Programming, Estrogen Regulation and
Promoter Characteristics of Cyp19 Genes in Teleost Fish. J. Steroid Biochem. Mol. Biol. 79, 305-314. doi:10.1016/s0960-0760(01)00147-9

Cano-Nicolau, J., Vaillant, C., Pellegrini, E., Charlier, T. D., Kah, O., and Coumailleau, P. (2016). Estrogenic Effects of Several BPA Analogs in the Developing Zebrafish Brain. Front. Neurosci. 10, 112. doi:10.3389/fnins.2016. 00112

Casals-Casas, C., and Desvergne, B. (2011). Endocrine Disruptors: from Endocrine to Metabolic Disruption. Annu. Rev. Physiol. 73, 135-162. doi:10.1146/ annurev-physiol-012110-142200

Cascio, C., Deidda, I., Russo, D., and Guarneri, P. (2015). The Estrogenic Retina: The Potential Contribution to Healthy Aging and Age-Related Neurodegenerative Diseases of the Retina. Steroids 103, 31-41. doi:10.1016/j. steroids.2015.08.002

Cascio, C., Russo, D., Drago, G., Galizzi, G., Passantino, R., Guarneri, R., et al. (2007). 17beta-estradiol Synthesis in the Adult Male Rat Retina. Exp. Eye Res. 85, 166-172. doi:10.1016/j.exer.2007.02.008

Castro, I. B., Machado, F. B., De Sousa, G. T., Paz-Villarraga, C., and Fillmann, G. (2021). How Protected Are marine Protected Areas: a Case Study of Tributyltin in Latin America. J. Environ. Manage. 278, 111543. doi:10.1016/j.jenvman.2020. 111543

Chang, J., Wang, M., Gui, W., Zhao, Y., Yu, L., and Zhu, G. (2012). Changes in Thyroid Hormone Levels during Zebrafish Development. Zoolog. Sci. 29, 181-184. doi:10.2108/zsj.29.181

Chapin, R., Adams, J., Boekelheide, K., Gray, J., Le, Hayward, S., Lees, P., et al. (2008). NTP-CERHR Expret Panel Report on the Reproductive and Developmental Toxicity of Bisphenol A. Birth Defects Res. B. Dev. Reprod. Toxicol. 83 (3), 157-395. doi:10.1002/bdrb.20147

Chien, L. C., Hung, T. C., Choang, K. Y., Yeh, C. Y., Meng, P. J., Shieh, M. J., et al. (2002). Daily Intake of TBT, $\mathrm{Cu}, \mathrm{Zn}, \mathrm{Cd}$ and as for Fishermen in Taiwan. Sci. Total Environ. 285, 177-185. doi:10.1016/s0048-9697(01)00916-0

Chung, E., Genco, M. C., Megrelis, L., and Ruderman, J. V. (2011). Effects of Bisphenol A and Triclocarban on Brain-specific Expression of Aromatase in Early Zebrafish Embryos. Proc. Natl. Acad. Sci. U S A. 108, 17732-17737. doi:10. 1073/pnas.1115187108

Clark, D. (1981). Visual Responses in Developing Zebrafish (Brachydanio Rerio). PhD Thesis. Eugene, OR: University of Oregon.

Connaughton, V. P., and Nelson, R. (2010). Spectral Responses in Zebrafish Horizontal Cells Include a Tetraphasic Response and a Novel UVDominated Triphasic Response. J. Neurophysiol. 104, 2407-2422. doi:10. 1152/jn.00644.2009

Cortez, V., Mann, M., Brann, D. W., and Vadlamudi, R. K. (2013). Extranuclear Signaling by Estrogen: Role in Breast Cancer Progression and Metastasis. Minerva Ginecol 62, 573-583.

Crowley-Perry, M., Barberio, A. J., Zeino, J., Winston, E. R., and Connaughton, V. P. (2021). Zebrafish Optomotor Response and Morphology Are Altered by Transient, Developmental Exposure to Bisphenol-A. J. Dev. Biol. 9, 14. doi:10. 3390/jdb9020014

Cui, J., Shen, Y., and Li, R. (2013). Estrogen Synthesis and Signaling Pathways during Aging: from Periphery to Brain. Trends Mol. Med. 19, 197-209. doi:10. 1016/j.molmed.2012.12.007

Darras, V. M., Hume, R., and Visser, T. J. (1999). Regulation of Thyroid Hormone Metabolism during Fetal Development. Mol. Cel Endocrinol 151, 37-47. doi:10. 1016/s0303-7207(99)00088-x

Darras, V. M., Van Herck, S. L., Heijlen, M., and De Groef, B. (2011). Thyroid Hormone Receptors in Two Model Species for Vertebrate Embryonic Development: Chicken and Zebrafish. J. Thyroid Res. 2011, 402320. doi:10. 4061/2011/402320

Denny, J. S., Tapper, M. A., Schmieder, P. K., Hornung, M. W., Jensen, K. M., Ankley, G. T., et al. (2009). Comparison of Relative Binding Affinities of Endocrine Active Compounds to Fathead Minnow and Rainbow trout Estrogen Receptors. Environ. Toxicol. Chem. 24, 2948-2953. doi:10.1897/04-595r.1

Deveau, C., Jiao, X., Suzuki, S. C., Krishnakumar, A., Yoshimatsu, T., Hejtmancik, J. F., et al. (2020). Thyroid Hormone Receptor Beta Mutations Alter Photoreceptor Development and Function in Danio rerio (Zebrafish). Plos Genet. 16, e1008869. doi:10.1371/journal.pgen.1008869

Diotel, N., Vaillant, C., Gabbero, C., Mironov, S., Fostier, A., Gueguen, M. M., et al. (2013). Effects of Estradiol in Adult Neurogenesis and Brain Repair in Zebrafish. Horm. Behav. 63, 193-207. doi:10.1016/j.yhbeh.2012.04.003 
Dong, W., Muramoto, W., Nagai, Y., Takehana, K., Stegeman, J. J., Teraoka, H., et al. (2006). Retinal Neuronal Cell Is a Toxicological Target of Tributyltin in Developing Zebrafish. J. Vet. Med. Sci. 68, 573-579. doi:10.1292/jvms.68.573

Dunn, T. W., Gebhardt, C., Naumann, E. A., Riegler, C., Ahrens, M. B., Engert, F., et al. (2016). Neural Circuits Underlying Visually Evoked Escapes in Larval Zebrafish. Neuron 89, 613-628. doi:10.1016/j.neuron.2015.12.021

Eldred, K. C., Hadyniak, S. E., Hussey, K. A., Brenerman, B., Zhang, P. W., Chamling, X., et al. (2018). Thyroid Hormone Signaling Specifies Cone Subtypes in Human Retinal Organoids. Science 362. doi:10.1126/science. aau6348

Endeman, D., Klaassen, L. J., and Kamermans, M. (2013). Action Spectra of Zebrafish Cone Photoreceptors. PLOS ONE 8, e68540. doi:10.1371/journal. pone. 0068540

Enright, J. M., Toomey, M. B., Sato, S. Y., Temple, S. E., Allen, J. R., Fujiwara, R., et al. (2015). Cyp27c1 Red-Shifts the Spectral Sensitivity of Photoreceptors by Converting Vitamin A1 into A2. Curr. Biol. 25, 3048-3057. doi:10.1016/j.cub.2015.10.018

Essner, J. J., Breuer, J. J., Essner, R. D., Fahrenkrug, S. C., and Hackett, P. B. (1997). The Zebrafish Thyroid Hormone Receptor Alpha 1 Is Expressed during Early Embryogenesis and Can Function in Transcriptional Repression. Differentiation 62, 107-117. doi:10.1046/j.1432-0436.1997.6230107.x

Farabollini, F., Porrini, S., and Dessi-Fulgherit, F. (1999). Perinatal Exposure to the Estrogenic Pollutant Bisphenol A Affects Behavior in Male and Female Rats. Pharmacol. Biochem. Behav. 64, 687-694. doi:10.1016/s0091-3057(99)00136-7

Fent, K., and Meier, W. (1992). Tributyltin-induced Effects on Early Life Stages of Minnows Phoxinus phoxinus. Arch. Environ. Contam. Toxicol. 22, 428-438. doi:10.1007/BF00212563

Flamant, F., Cheng, S. Y., Hollenberg, A. N., Moeller, L. C., Samarut, J., Wondisford, F. E., et al. (2017). Thyroid Hormone Signaling Pathways: Time for a More Precise Nomenclature. Endocrinology 158, 2052-2057. doi:10.1210/en.2017-00250

Froehlicher, M., Liedtke, A., Groh, K., López-Schier, H., Neuhauss, S. C., Segner, H., et al. (2009). Estrogen Receptor Subtype Beta2 Is Involved in Neuromast Development in Zebrafish (Danio rerio) Larvae. Dev. Biol. 330, 32-43. doi:10. 1016/j.ydbio.2009.03.005

Gellinas, D., and Callard, G. V. (1993). Immunocytochemical and Biochemical Evidence for Aromatase in Neurons of the Retina, Optic Tectum and Retinotectal Pathways in Goldfish. J. Neuroendocrinology 5, 635-641.

Gerlai, R. (2016). Learning and Memory in Zebrafish (Danio rerio). Methods Cel Biol 134, 551-586. doi:10.1016/bs.mcb.2016.02.005

Gibert, Y., Sassi-Messai, S., Fini, J. B., Bernard, L., Zalko, D., Cravedi, J. P., et al. (2011). Bisphenol A Induces Otolith Malformations during Vertebrate Embryogenesis. BMC Dev. Biol. 11, 4. doi:10.1186/1471-213X-11-4

Gipperth, L. (2009). The Legal Design of the International and European Union Ban on Tributyltin Antifouling Paint: Direct and Indirect Effects. J. Environ. Manage. 90 (Suppl. 1), S86-S95. doi:10.1016/j.jenvman.2008.08.013

Glaschke, A., Weiland, J., Del Turco, D., Steiner, M., Peichl, L., and Glösmann, M. (2011). Thyroid Hormone Controls Cone Opsin Expression in the Retina of Adult Rodents. J. Neurosci. 31, 4844-4851. doi:10.1523/JNEUROSCI.6181-10. 2011

Glass, C. K., Holloway, J. M., Devary, O. V., and Rosenfeld, M. G. (1988). The Thyroid Hormone Receptor Binds with Opposite Transcriptional Effects to a Common Sequence Motif in Thyroid Hormone and Estrogen Response Elements. Cell 54, 313-323. doi:10.1016/0092-8674(88)90194-8

González, A., and Piferrer, F. (2002). Characterization of Aromatase Activity in the Sea Bass: Effects of Temperature and Different Catalytic Properties of Brain and Ovarian Homogenates and Microsomes. J. Exp. Zool 293, 500-510. doi:10.1002/ jez.90005

Gothié, J. D., Vancamp, P., Demeneix, B., and Remaud, S. (2019). Thyroid Hormone Regulation of Neural Stem Cell Fate: from Development to Ageing. Acta Physiol. (Oxf) 228, e13316. doi:10.1111/apha.13316

Gould, C. J., Saldanha, C. J., and Connaughton, V. P. (2019). Acute Exposure to 4OH-A, Not PCB1254, Alters Brain Aromatase Activity but Does Not Adversely Affect Growth in Zebrafish. Environ. Toxicol. Pharmacol. 68, 133-140. doi:10. 1016/j.etap.2019.02.010

Gould, C. J., Wiegand, J. L., and Connaughton, V. P. (2017). Acute Developmental Exposure to 4-hydroxyandrostenedione Has a Long-Term Effect on Visually-Guided Behaviors. Neurotoxicol Teratol 64, 45-49. doi:10. 1016/j.ntt.2017.10.003
Graupner, G., Zhang, X. K., Tzukerman, M., Wills, K., Hermann, T., and Pfahl, M. (1991). Thyroid Hormone Receptors Repress Estrogen Receptor Activation of a TRE. Mol. Endocrinol. 5, 365-372. doi:10.1210/mend-5-3-365

Group, E. W. (2013). Dirty Dozen List of Endocrine Disruptors [Online]. Available at: http://www.ewg.org/research/dirty-dozen-list-endocrine-disruptors (Accessed, 2016).

Hamad, A., Kluk, M., Fox, J., Park, M., and Turner, J. E. (2007). The Effects of Aromatase Inhibitors and Selective Estrogen Receptor Modulators on Eye Development in the Zebrafish (Danio rerio). Curr. Eye Res. 32, 819-827. doi:10.1080/02713680701573712

Hano, T., Oshima, Y., Kim, S. G., Satone, H., Oba, Y., Kitano, T., et al. (2007). Tributyltin Causes Abnormal Development in Embryos of Medaka, Oryzias latipes. Chemosphere 69, 927-933. doi:10.1016/j.chemosphere.2007.05.093

Hao, R., Bondesson, M., Singh, A. V., Riu, A., Mccollum, C. W., Knudsen, T. B., et al. (2013). Identification of Estrogen Target Genes during Zebrafish Embryonic Development through Transcriptomic Analysis. PLoS One 8, e79020. doi:10.1371/journal.pone.0079020

Harpavat, S., and Cepko, C. L. (2003). Thyroid Hormone and Retinal Development: an Emerging Field. Thyroid 13, 1013-1019. doi:10.1089/ 105072503770867183

Hatch, E. E., Nelson, J. W., Stahlhut, R. W., and Webster, T. F. (2010). Association of Endocrine Disruptors and Obesity: Perspectives from Epidemiological Studies. Int. J. Androl. 33, 324-332. doi:10.1111/j.1365-2605.2009.01035.x

Hayashi, L., Sheth, M., Young, A., Kruger, M., Wayman, G. A., and Coffin, A. B. (2015). The Effect of the Aquatic Contaminants Bisphenol-A and PCB-95 on the Zebrafish Lateral Line. Neurotoxicology 46, 125-136. doi:10.1016/j.neuro. 2014.12.010

Haynes, J.-D., Deichmann, R., and Rees, G. (2005). Eye-specific Effects of Binocular Rivalry in the Human Lateral Geniculate Nucleus. Nature 438, 496-499. doi:10. 1038/nature04169

Heimeier, R. A., Das, B., Buchholz, D. R., and Shi, Y. B. (2009). The Xenoestrogen Bisphenol A Inhibits Postembryonic Vertebrate Development by Antagonizing Gene Regulation by Thyroid Hormone. Endocrinology 150, 2964-2973. doi:10. 1210/en.2008-1503

Heindel, J. J., Newbold, R., and Schug, T. T. (2015). Endocrine Disruptors and Obesity. Nat. Rev. Endocrinol. 11, 653-661. doi:10.1038/nrendo.2015.163

Houbrechts, A. M., Vergauwen, L., Bagci, E., Van Houcke, J., Heijlen, M., Kulemeka, B., et al. (2016). Deiodinase Knockdown Affects Zebrafish Eye Development at the Level of Gene Expression, Morphology and Function. Mol. Cel Endocrinol 424, 81-93. doi:10.1016/j.mce.2016.01.018

Howdeshell, K. L. (2002). A Model of the Development of the Brain as a Construct of the Thyroid System. Environ. Health Perspect. 110 (Suppl. 3), 337-348. doi:10.1289/ehp.02110s3337

Howe, K., Clark, M. D., Torroja, C. F., Torrance, J., Berthelot, C., Muffato, M., et al. (2013). The Zebrafish Reference Genome Sequence and its Relationship to the Human Genome. Nature 496, 498-503. doi:10.1038/nature12111

Hunter, P. R., Lowe, A. S., Thompson, I. D., and Meyer, M. P. (2013). Emergent Properties of the Optic Tectum Revealed by Population Analysis of Direction and Orientation Selectivity. J. Neurosci. 33, 13940-13945. doi:10.1523/ JNEUROSCI.1493-13.2013

IMO (2019). International Convention on the Control of Harmful Anti-fouling Systems on Ships [Online]. London: International Maritime Organization. Available at: https://www.imo.org (Accessed, 2021).

Jašarević, E., Sieli, P. T., Twellman, E. E., Welsh, T. H., Jr, Schachtman, T. R., Roberts, R. M., et al. (2011). Disruption of Adult Expression of Sexually Selected Traits by Developmental Exposure to Bisphenol A. Proc. Natl. Acad. Sci. U S A. 108, 11715-11720. doi:10.1073/pnas.1107958108

Jayasinghe, B. S., and Volz, D. C. (2011). Aberrant Ligand-Induced Activation of G Protein-Coupled Estrogen Receptor 1 (GPER) Results in Developmental Malformations during Vertebrate Embryogenesis. Toxicol. Sci. 125, 262-273. doi:10.1093/toxsci/kfr269

Jones, M. R. L., and Ross, P. M. (2018). Recovery of the New Zealand Muricid Dogwhelk Haustrum Scobina from TBT-Induced Imposex. Mar. Pollut. Bull. 126, 396-401. doi:10.1016/j.marpolbul.2017.11.034

Jung, K. K., Kim, S. Y., Kim, T. G., Kang, J. H., Kang, S. Y., Cho, J. Y., et al. (2007). Differential Regulation of Thyroid Hormone Receptor-Mediated Function by Endocrine Disruptors. Arch. Pharm. Res. 30, 616-623. doi:10. 1007/BF02977657 
Kajta, M., and Wójtowicz, A. K. (2013). Impact of Endocrine-Disrupting Chemicals on Neural Development and the Onset of Neurological Disorders. Pharmacol. Rep. 65, 1632-1639. doi:10.1016/s1734-1140(13) 71524-x

Kim, M. E., Park, H. R., Gong, E. J., Choi, S. Y., Kim, H. S., and Lee, J. (2011). Exposure to Bisphenol A Appears to Impair Hippocampal Neurogenesis and Spatial Learning and Memory. Food Chem. Toxicol. 49, 3383-3389. doi:10. 1016/j.fct.2011.09.017

Kimmel, C. B., Ballard, W. W., Kimmel, S. R., Ullmann, B., and Schilling, T. F. (1995). Stages of Embryonic Development of the Zebrafish. Dev. Dyn. 203, 253-310. doi:10.1002/aja.1002030302

Kinch, C. D., Ibhazehiebo, K., Jeong, J. H., Habibi, H. R., and Kurrasch, D. M. (2015). Low-dose Exposure to Bisphenol A and Replacement Bisphenol S Induces Precocious Hypothalamic Neurogenesis in Embryonic Zebrafish. Proc. Natl. Acad. Sci. U S A. 112, 1475-1480. doi:10.1073/pnas.1417731112

Kishida, M., and Callard, G. V. (2001). Distinct Cytochrome P450 Aromatase Isoforms in Zebrafish (Danio rerio) Brain and Ovary Are Differentially Programmed and Estrogen Regulated during Early Development. Endocrinology 142, 740-750. doi:10.1210/endo.142.2.7928

Kishida, M., Mclellan, M., Miranda, J. A., and Callard, G. V. (2001). Estrogen and Xenoestrogens Upregulate the Brain Aromatase Isoform (P450aromB) and Perturb Markers of Early Development in Zebrafish (Danio rerio). Comp. Biochem. Physiol. B Biochem. Mol. Biol. 129, 261-268. doi:10.1016/s10964959(01)00319-0

Klinge, C. M. (2001). Estrogen Receptor Interaction with Estrogen Response Elements. Nucleic Acids Res. 29, 2905-2919. doi:10.1093/nar/29.14.2905

Kobayashi, K., Kobayashi, H., Ueda, M., and Honda, Y. (1998). Estrogen Receptor Expression in Bovine and Rat Retinas. Invest. Ophthalmol. Vis. Sci. 39, 2105-2110.

Köhrle, J., and Frädrich, C. (2021). Thyroid Hormone System Disrupting Chemicals. Best Pract. Res. Clin. Endocrinol. Metab. 35, 101562. doi:10.1016/ j.beem.2021.101562

Kolpin, D. W., Furlong, E. T., Meyer, M. T., Thurman, E. M., and Zaugg, S. D. (2002). Pharmaceuticals, Hormones, and Other Organic Wastewater Contaminants in US Streams, 1999-2000: A National Reconnaissance. Environ. Sci. Technol. 36 (6), 1202-1211.

Komoike, Y., Matsuoka, M., and Kosaki, K. (2013). Potential Teratogenicity of Methimazole: Exposure of Zebrafish Embryos to Methimazole Causes Similar Developmental Anomalies to Human Methimazole Embryopathy. Birth Defects Res. B Dev. Reprod. Toxicol. 98, 222-229. doi:10.1002/bdrb.21057

Krens, S. F., He, S., Spaink, H. P., and Snaar-Jagalska, B. E. (2006). Characterization and Expression Patterns of the MAPK Family in Zebrafish. Gene Expr. Patterns 6, 1019-1026. doi:10.1016/j.modgep.2006.04.008

Lakind, J. S., and Naiman, D. Q. (2011). Daily Intake of Bisphenol A and Potential Sources of Exposure: 2005-2006 National Health and Nutrition Examination Survey. J. Expo. Sci. Environ. Epidemiol. 21, 272-279. doi:10.1038/jes.2010.9

Lassiter, C. S., Kelley, B., and Linney, E. (2002). Genomic Structure and Embryonic Expression of Estrogen Receptor Beta a (ERbetaa) in Zebrafish (Danio rerio). Gene 299, 141-151. doi:10.1016/s0378-1119(02)01050-8

Lazar, M. A., Berrodin, T. J., and Harding, H. P. (1991). Differential DNA Binding by Monomeric, Homodimeric, and Potentially Heteromeric Forms of the Thyroid Hormone Receptor. Mol. Cel Biol 11, 5005-5015. doi:10.1128/mcb. 11.10 .5005

Le Page, Y., Vosges, M., Servili, A., Brion, F., and Kah, O. (2011). Neuroendocrine Effects of Endocrine Disruptors in Teleost Fish. J. Toxicol. Environ. Health B Crit. Rev. 14, 370-386. doi:10.1080/10937404.2011.578558

Lee, S., and Privalsky, M. L. (2005). Heterodimers of Retinoic Acid Receptors and Thyroid Hormone Receptors Display Unique Combinatorial Regulatory Properties. Mol. Endocrinol. 19, 863-878. doi:10.1210/me.2004-0210

Lephart, E. D. (1996). A Review of Brain Aromatase Cytochrome P450. Brain Res. Brain Res. Rev. 22, 1-26. doi:10.1016/0165-0173(96)00002-1

Levin, E. R. (2002). Cellular Functions of Plasma Membrane Estrogen Receptors. Steroids 67, 471-475. doi:10.1016/s0039-128x(01)00179-9

Li, D., Li, T., Wang, F., Tian, H., and Samuels, H. H. (2002). Functional Evidence for Retinoid X Receptor (RXR) as a Nonsilent Partner in the Thyroid Hormone Receptor/RXR Heterodimer. Mol. Cel Biol 22, 5782-5792. doi:10.1128/mcb.22. $16.5782-5792.2002$
Li, D., Yamada, T., Wang, F., Vulin, A. I., and Samuels, H. H. (2004). Novel Roles of Retinoid X Receptor (RXR) and RXR Ligand in Dynamically Modulating the Activity of the Thyroid Hormone Receptor/RXR Heterodimer. J. Biol. Chem. 279, 7427-7437. doi:10.1074/jbc.M311596200

Li, Y. N., Tsujimura, T., Kawamura, S., and Dowling, J. E. (2012). Bipolar CellPhotoreceptor Connectivity in the Zebrafish (Danio rerio) Retina. J. Comp. Neurol. 520, 3786-3802. doi:10.1002/cne.23168

Li, Z. H., and Li, P. (2021). Effects of the Tributyltin on the Blood Parameters, Immune Responses and Thyroid Hormone System in Zebrafish. Environ. Pollut. 268, 115707. doi:10.1016/j.envpol.2020.115707

Liang, X., Souders, C. L., Iii, Zhang, J., and Martyniuk, C. J. (2017). Tributyltin Induces Premature Hatching and Reduces Locomotor Activity in Zebrafish (Danio rerio) Embryos/larvae at Environmentally Relevant Levels. Chemosphere 189, 498-506. doi:10.1016/j.chemosphere.2017.09.093

Link, B. A., and Collery, R. F. (2015). Zebrafish Models of Retinal Disease. Annu. Rev. Vis. Sci. 1, 125-153. doi:10.1146/annurev-vision-082114-035717

Liu, W., Zhang, X., Wei, P., Tian, H., Wang, W., and Ru, S. (2017). Long-term Exposure to Bisphenol S Damages the Visual System and Reduces the Tracking Capability of Male Zebrafish (Danio rerio). J. Appl. Toxicol. 38, 248-258. doi:10. 1002/jat.3519

Liu, Y. W., Lo, L. J., and Chan, W. K. (2000). Temporal Expression and T3 Induction of Thyroid Hormone Receptors Alphal and Betal during Early Embryonic and Larval Development in Zebrafish, Danio rerio. Mol. Cel Endocrinol 159, 187-195. doi:10.1016/s0303-7207(99)00193-8

Lovato, A. K., Creton, R., and Colwill, R. M. (2017). Effects of Embryonic Exposure to Polychlorinated Biphenyls (PCBs) on Larval Zebrafish Behavior. Neurotoxicol Teratol 53, 1-10. doi:10.1016/j.ntt.2015.11.002

Luo, J., and Liu, D. (2020). Does GPER Really Function as a G Protein-Coupled Estrogen Receptor In Vivo? Front. Endocrinol. (Lausanne) 11, 148. doi:10.3389/ fendo. 2020.00148

Lyssimachou, A., Jenssen, B. M., and Arukwe, A. (2006). Brain Cytochrome P450 Aromatase Gene Isoforms and Activity Levels in Atlantic Salmon after Waterborne Exposure to Nominal Environmental Concentrations of the Pharmaceutical Ethynylestradiol and Antifoulant Tributyltin. Toxicol. Sci. 91, 82-92. doi:10.1093/toxsci/kfj136

Mackin, R. D., Frey, R. A., Gutierrez, C., Farre, A. A., Kawamura, S., Mitchell, D. M., et al. (2019). Endocrine Regulation of Multichromatic Color Vision. Proc. Natl. Acad. Sci. U S A. 116, 16882-16891. doi:10.1073/pnas.1904783116

Mangiamele, L. A., Gomez, J. R., Curtis, N. J., and Thompson, R. R. (2017). GPER/ GPR30, a Membrane Estrogen Receptor, Is Expressed in the Brain and Retina of a Social Fish (Carassius auratus) and Colocalizes with Isotocin. J. Comp. Neurol. 525, 252-270. doi:10.1002/cne.24056

Marelli, F., Carra, S., Agostini, M., Cotelli, F., Peeters, R., Chatterjee, K., et al. (2016). Patterns of Thyroid Hormone Receptor Expression in Zebrafish and Generation of a Novel Model of Resistance to Thyroid Hormone Action. Mol. Cel Endocrinol 424, 102-117. doi:10.1016/j.mce.2016.01.020

Mayer, I., Borg, B., Berglund, I., and Lambert, J. G. (1991). Effects of Castration and Androgen Treatment on Aromatase Activity in the Brain of Mature Male Atlantic salmon (Salmo salar L.) Parr. Gen. Comp. Endocrinol. 82, 86-92. doi:10.1016/0016-6480(91)90299-1

Mcallister, B. G., and Kime, D. E. (2003). Early Life Exposure to Environmental Levels of the Aromatase Inhibitor Tributyltin Causes Masculinisation and Irreversible Sperm Damage in Zebrafish (Danio rerio). Aquat. Toxicol. 65, 309-316. doi:10.1016/s0166-445x(03)00154-1

Mccarthy, M. M. (2008). Estradiol and the Developing Brain. Physiol. Rev. 88, 91-124. doi:10.1152/physrev.00010.2007

Mccarthy, M. M. (2009). The Two Faces of Estradiol: Effects on the Developing Brain. Neuroscientist 15, 599-610. doi:10.1177/1073858409340924

Mcginnis, C. L., and Crivello, J. F. (2011). Elucidating the Mechanism of Action of Tributyltin (TBT) in Zebrafish. Aquat. Toxicol. 103, 25-31. doi:10.1016/j. aquatox.2011.01.005

Meier, A., Nelson, R., and Connaughton, V. P. (2018). Color Processing in Zebrafish Retina. Front Cel Neurosci 12, 327. doi:10.3389/fncel.2018.00327

Menuet, A., Pellegrini, E., Anglade, I., Blaise, O., Laudet, V., Kah, O., et al. (2002). Molecular Characterization of Three Estrogen Receptor Forms in Zebrafish: Binding Characteristics, Transactivation Properties, and Tissue Distributions. Biol. Reprod. 66, 1881-1892. doi:10.1095/biolreprod66.6.1881 
Menuet, A., Pellegrini, E., Brion, F., Gueguen, M. M., Anglade, I., Pakdel, F., et al. (2005). Expression and Estrogen-dependent Regulation of the Zebrafish Brain Aromatase Gene. J. Comp. Neurol. 485, 304-320. doi:10.1002/cne.20497

Moriyama, K., Tagami, T., Akamizu, T., Usui, T., Saijo, M., Kanamoto, N., et al. (2002). Thyroid Hormone Action Is Disrupted by Bisphenol A as an Antagonist. J. Clin. Endocrinol. Metab. 87, 5185-5190. doi:10.1210/jc.2002020209

Mouriec, K., Lareyre, J. J., Tong, S. K., Le Page, Y., Vaillant, C., Pellegrini, E., et al. (2009). Early Regulation of Brain Aromatase (Cyp19a1b) by Estrogen Receptors during Zebrafish Development. Dev. Dyn. 238, 2641-2651. doi:10.1002/dvdy. 22069

Muto, A., and Kawakami, K. (2013). Prey Capture in Zebrafish Larvae Serves as a Model to Study Cognitive Functions. Front. Neural Circuits 7, 110. doi:10.3389/ fncir.2013.00110

Muto, A., Orger, M. B., Wehman, A. M., Smear, M. C., Kay, J. N., Page-Mccaw, P. S., et al. (2005). Forward Genetic Analysis of Visual Behavior in Zebrafish. Plos Genet. 1, e66. doi:10.1371/journal.pgen.0010066

Nakajima, Y., Goldblum, R. M., and Midoro-Horiuti, T. (2012). Fetal Exposure to Bisphenol A as a Risk Factor for the Development of Childhood Asthma: an Animal Model Study. Environ. Health 11, 8. doi:10.1186/1476-069X-11-8

Nasri, A., Mezni, A., Lafon, P.-A., Wahbi, A., Cubedo, N., Clair, P., et al. (2021). Ethinylestradiol (EE2) Residues from Birth Control Pills Impair Nervous System Development and Swimming Behavior of Zebrafish Larvae. Sci. Total Environ. 770, 145272. doi:10.1016/j.scitotenv.2021.145272

Nelson, B. P., Henriet, R. P., Holt, A. W., Bopp, K. C., Houser, A. P., Allgood, O. E., Jr, et al. (2008). The Role of Estrogen in the Developmental Appearance of Sensory-Motor Behaviors in the Zebrafish (Danio rerio): the Characterization of the "listless" Model. Brain Res. 1222, 118-128. doi:10.1016/j.brainres.2008. 05.049

Nelson, R. F., Balraj, A., Suresh, T., Torvund, M., and Patterson, S. S. (2019). Strain Variations in Cone Wavelength Peaks In Situ during Zebrafish Development. Vis. Neurosci. 36, E010. doi:10.1017/S0952523819000075

Neuhauss, S. C. (2003). Behavioral Genetic Approaches to Visual System Development and Function in Zebrafish. J. Neurobiol. 54, 148-160. doi:10. 1002/neu.10165

Nikoleris, L., Hultin, C. L., Hallgren, P., and Hansson, M. C. (2016). 17aEthinylestradiol (EE2) Treatment of Wild Roach (Rutilus rutilus) during Early Life Development Disrupts Expression of Genes Directly Involved in the Feedback Cycle of Estrogen. Comp. Biochem. Physiol. C Toxicol. Pharmacol. 180, 56-64. doi:10.1016/j.cbpc.2015.12.002

Noyes, P. D., Friedman, K. P., Browne, P., Haselman, J. T., Gilbert, M. E., Hornung, M. W., et al. (2019). Evaluating Chemicals for Thyroid Disruption: Opportunities and Challenges with In Vitro Testing and Adverse Outcome Pathway Approaches. Environ. Health Perspect. 127, 95001. doi:10.1289/ EHP5297

Orger, M. B., Gahtan, E., Muto, A., Page-Mccaw, P., Smear, M. C., and Baier, H. (2004). Behavioral Screening Assays in Zebrafish. Methods Cel Biol 77, 53-68. doi:10.1016/s0091-679x(04)77003-x

Ortiz-Villanueva, E., Jaumot, J., Martínez, R., Navarro-Martín, L., Piña, B., and Tauler, R. (2018). Assessment of Endocrine Disruptors Effects on Zebrafish (Danio rerio) Embryos by Untargeted LC-HRMS Metabolomic Analysis. Sci. Total Environ. 635, 156-166. doi:10.1016/j.scitotenv.2018.03.369

Paige, L. A., Christensen, D. J., Grøn, H., Norris, J. D., Gottlin, E. B., Padilla, K. M., et al. (1999). Estrogen Receptor (ER) Modulators Each Induce Distinct Conformational Changes in ER Alpha and ER Beta. Proc. Natl. Acad. Sci. U S A. 96, 3999-4004. doi:10.1073/pnas.96.7.3999

Pasmanik, M., and Callard, G. V. (1988). Changes in Brain Aromatase and 5 Alpha-Reductase Activities Correlate Significantly with Seasonal Reproductive Cycles in Goldfish (Carassius auratus). Endocrinology 122, 1349-1356. doi:10.1210/endo-122-4-1349

Patrick, L. (2009). Thyroid Disruption: Mechanism and Clinical Implications in Human Health. Altern. Med. Rev. 14, 326-346.

Peachey, N. S., Ray, T. A., Florijn, R., Rowe, L. B., Sjoerdsma, T., ContrerasAlcantara, S., et al. (2012). GPR179 Is Required for Depolarizing Bipolar Cell Function and Is Mutated in Autosomal-Recessive Complete Congenital Stationary Night Blindness. Am. J. Hum. Genet. 90, 331-339. doi:10.1016/j. ajhg.2011.12.006
Pellegrini, E., Menuet, A., Lethimonier, C., Adrio, F., Gueguen, M. M., Tascon, C., et al. (2005). Relationships between Aromatase and Estrogen Receptors in the Brain of Teleost Fish. Gen. Comp. Endocrinol. 142, 60-66. doi:10.1016/j.ygcen. 2004.12.003

Pellegrini, E., Mouriec, K., Anglade, I., Menuet, A., Le Page, Y., Gueguen, M. M., et al. (2007). Identification of Aromatase-Positive Radial Glial Cells as Progenitor Cells in the Ventricular Layer of the Forebrain in Zebrafish. J. Comp. Neurol. 501, 150-167. doi:10.1002/cne.21222

Porazzi, P., Calebiro, D., Benato, F., Tiso, N., and Persani, L. (2009). Thyroid Gland Development and Function in the Zebrafish Model. Mol. Cel Endocrinol 312, 14-23. doi:10.1016/j.mce.2009.05.011

Qiu, W., Zhao, Y., Yang, M., Farajzadeh, M., Pan, C., and Wayne, N. L. (2016). Actions of Bisphenol A and Bisphenol S on the Reproductive Neuroendocrine System during Early Development in Zebrafish. Endocrinology 157, 636-647. doi:10.1210/en.2015-1785

Ramírez-Montero, M. d. C., Gómez-Oliván, L. M., Gutiérrez-Noya, V. M., OrozcoHernández, J. M., Islas-Flores, H., Elizalde-Velázquez, G. A., et al. (2022). Acute Exposure to 17-a-Ethinylestradiol Disrupt the Embryonic Development and Oxidative Status of Danio rerio. Comp. Biochem. Physiol. C: Toxicol. Pharmacol. 251, 109199. doi:10.1016/j.cbpc.2021.109199

Raymond, P. A., Barthel, L. K., and Curran, G. A. (1995). Developmental Patterning of Rod and Cone Photoreceptors in Embryonic Zebrafish. J. Comp. Neurol. 359, 537-550. doi:10.1002/cne.903590403

Rehberger, K., Baumann, L., Hecker, M., and Braunbeck, T. (2018). Intrafollicular Thyroid Hormone Staining in Whole-Mount Zebrafish (Danio rerio) Embryos for the Detection of Thyroid Hormone Synthesis Disruption. Fish. Physiol. Biochem. 44, 997-1010. doi:10.1007/s10695-018-0488-y

Reider, M., and Connaughton, V. P. (2014). Developmental Exposure to Methimazole Increases Anxiety Behavior in Zebrafish. Behav. Neurosci. 129, 634-642. doi:10.1037/bne0000087

Richter, C. A., Taylor, J. A., Ruhlen, R. L., Welshons, W. V., and Vom Saal, F. S. (2007). Estradiol and Bisphenol A Stimulate Androgen Receptor and Estrogen Receptor Gene Expression in Fetal Mouse Prostate Mesenchyme Cells. Environ. Health Perspect. 115, 902-908. doi:10.1289/ehp.9804

Roberts, M. R., Srinivas, M., Forrest, D., Morreale de Escobar, G., and Reh, T. A. (2006). Making the Gradient: Thyroid Hormone Regulates Cone Opsin Expression in the Developing Mouse Retina. Proc. Natl. Acad. Sci. U S A. 103, 6218-6223. doi:10.1073/pnas.0509981103

Roque, C., and Baltazar, G. (2019). G Protein-Coupled Estrogen Receptor 1 (GPER) Activation Triggers Different Signaling Pathways on Neurons and Astrocytes. Neural Regen. Res. 14, 2069-2070. doi:10.4103/1673-5374.262577

Rouleau, C., Xiong, Z. H., Pacepavicius, G., and Huang, G. L. (2003). Uptake of Waterborne Tributyltin in the Brain of Fish: Axonal Transport as a Proposed Mechanism. Environ. Sci. Technol. 37, 3298-3302. doi:10.1021/es020984n

Saili, K. S., Corvi, M. M., Weber, D. N., Patel, A. U., Das, S. R., Przybyla, J., et al. (2012). Neurodevelopmental Low-Dose Bisphenol A Exposure Leads to Early Life-Stage Hyperactivity and Learning Deficits in Adult Zebrafish. Toxicology 291, 83-92. doi:10.1016/j.tox.2011.11.001

Santos, M. M., Micael, J., Carvalho, A. P., Morabito, R., Booy, P., Massanisso, P., et al. (2006). Estrogens Counteract the Masculinizing Effect of Tributyltin in Zebrafish. Comp. Biochem. Physiol. C Toxicol. Pharmacol. 142, 151-155. doi:10. 1016/j.cbpc.2005.11.014

Sawyer, S. J., Gerstner, K. A., and Callard, G. V. (2006). Real-time PCR Analysis of Cytochrome P450 Aromatase Expression in Zebrafish: Gene Specific Tissue Distribution, Sex Differences, Developmental Programming, and Estrogen Regulation. Gen. Comp. Endocrinol. 147, 108-117. doi:10.1016/j.ygcen.2005. 12.010

Schmidt, R., Strähle, U., and Scholpp, S. (2013). Neurogenesis in Zebrafish - from Embryo to Adult. Neural Dev. 8, 3. doi:10.1186/1749-8104-8-3

Schmitt, E. A., and Dowling, J. E. (1994). Early Eye Morphogenesis in the Zebrafish, Brachydanio Rerio. J. Comp. Neurol. 344, 532-542. doi:10.1002/cne.903440404

Schmitt, E. A., and Dowling, J. E. (1999). Early Retinal Development in the Zebrafish, Danio rerio: Light and Electron Microscopic Analyses. J. Comp. Neurol. 404, 515-536. doi:10.1002/(sici)1096-9861(19990222)404:4<515::aidcne8>3.0.co;2-a

Schönfelder, G., Wittfoht, W., Hopp, H., Talsness, C. E., Paul, M., and Chahoud, I. (2002). Parent Bisphenol A Accumulation in the Human Maternal-Fetal- 
Placental Unit. Environ. Health Perspect. 110, A703-A707. doi:10.1289/ehp. 110-1241091

Schøyen, M., Green, N. W., Hjermann, D. Ø., Tveiten, L., Beylich, B., Øxnevad, S., et al. (2019). Levels and Trends of Tributyltin (TBT) and Imposex in Dogwhelk (Nucella lapillus) along the Norwegian Coastline from 1991 to 2017. Mar. Environ. Res. 144, 1-8. doi:10.1016/j.marenvres.2018.11.011

Scott, R. E., Wu-Peng, X. S., Yen, P. M., Chin, W. W., and Pfaff, D. W. (1997). Interactions of Estrogen- and Thyroid Hormone Receptors on a Progesterone Receptor Estrogen Response Element (ERE) Sequence: a Comparison with the Vitellogenin A2 Consensus ERE. Mol. Endocrinol. 11, 1581-1592. doi:10.1210/ mend.11.11.0003

Sellitti, D. F., and Suzuki, K. (2014). Intrinsic Regulation of Thyroid Function by Thyroglobulin. Thyroid 24, 625-638. doi:10.1089/thy.2013.0344

Shi, Y., Chen, C., Li, M., Liu, L., Dong, K., Chen, K., et al. (2021). Oral Exposure to Tributyltin Induced Behavioral Abnormality and Oxidative Stress in the Eyes and Brains of Juvenile Japanese Medaka (Oryzias latipes). Antioxidants (Basel) 10, 1647. doi:10.3390/antiox10111647

Shi, Y., Liu, X., Zhu, P., Li, J., Sham, K. W., Cheng, S. H., et al. (2013). G-proteincoupled Estrogen Receptor 1 Is Involved in Brain Development during Zebrafish (Danio rerio) Embryogenesis. Biochem. Biophys. Res. Commun. 435, 21-27. doi:10.1016/j.bbrc.2013.03.130

Showalter, S., and Savarese, J. (2004). Restrictions on the Use of marine Antifouling Paints Containing Tributyltin and Copper.

Silva, N., Louro, B., Trindade, M., Power, D. M., and Campinho, M. A. (2017). Transcriptomics Reveal an Integrative Role for Maternal Thyroid Hormones during Zebrafish Embryogenesis. Sci. Rep. 7 (1), 1-11. doi:10.1038/s41598-01716951-9

Song, R., Lin, H., Chen, Y., Zhang, X., and Feng, W. (2017). Effects of Methimazole and Propylthiouracil Exposure during Pregnancy on the Risk of Neonatal Congenital Malformations: A Meta-Analysis. PLoS One 12, e0180108. doi:10. 1371/journal.pone.0180108

Suzuki, S. C., Bleckert, A., Williams, P. R., Takechi, M., Kawamura, S., and Wong, R. O. (2013). Cone Photoreceptor Types in Zebrafish Are Generated by Symmetric Terminal Divisions of Dedicated Precursors. Proc. Natl. Acad. Sci. U S A. 110, 15109-15114. doi:10.1073/pnas.1303551110

Takahashi, O., and Oishi, S. (2000). Disposition of Orally Administered 2,2-Bis(4Hydroxyphenyl)propane (Bisphenol A) in Pregnant Rats and the Placental Transfer to Fetuses. Environ. Health Perspect. 108, 931-935. doi:10.1289/ehp. 00108931

Takechi, M., and Kawamura, S. (2005). Temporal and Spatial Changes in the Expression Pattern of Multiple Red and green Subtype Opsin Genes during Zebrafish Development. J. Exp. Biol. 208, 1337-1345. doi:10.1242/jeb. 01532

Tang, Z., Liu, Z.-H., Wang, H., Dang, Z., and Liu, Y. (2021). A Review of $17 \alpha-$ Ethynylestradiol (EE2) in Surface Water across 32 Countries: Sources, Concentrations, and Potential Estrogenic Effects. J. Environ. Manage. 292, 112804. doi:10.1016/j.jenvman.2021.112804

Tata, J. R. (2005). One Hundred Years of Hormones. EMBO Rep. 6, 490-496. doi:10.1038/sj.embor.7400444

Thisse, B., and Thisse, C. (20142004). Fast Release Clones: A High Throughput Expression analysisZFIN Direct Data Submission. http://zfin.org.

Thomas, P., Alyea, R., Pang, Y., Peyton, C., Dong, J., and Berg, A. H. (2010). Conserved Estrogen Binding and Signaling Functions of the G Protein-Coupled Estrogen Receptor 1 (GPER) in Mammals and Fish. Steroids 75, 595-602. doi:10.1016/j.steroids.2009.11.005

Thomas, P., and Dong, J. (2006). Binding and Activation of the SevenTransmembrane Estrogen Receptor GPR30 by Environmental Estrogens: A Potential Novel Mechanism of Endocrine Disruption. J. Steroid Biochem. Mol. Biol. 102, 175-179. doi:10.1016/j.jsbmb.2006.09.017

Tingaud-Sequeira, A., André, M., Forgue, J., Barthe, C., and Babin, P. J. (2004). Expression Patterns of Three Estrogen Receptor Genes during Zebrafish (Danio rerio) Development: Evidence for High Expression in Neuromasts. Gene Expr. Patterns 4, 561-568. doi:10.1016/j.modgep.2004.02.002

Torvund, M., Ma, T., Connaughton, V., Ono, F., and Nelson, B. (2016). Cone Signals in the Monostratified Amacrine Cells of Adult Zebrafish Retina. J. Comp. Neurol. 525 (7), 1532-1557. doi:10.1002/cne.24107

Trimmers, R., Labert, J., Peute, J., Vullings, H., and Van Oordt, P. (1987). Localization of Aromatase in the Brain of the Male African Catfish, Clarias gariepinus (Burchell), by Microdissection and Biochemical Identification. J. Comp. Neurol. 258, 369-377.

Tse, W. K., Yeung, B. H., Wan, H. T., and Wong, C. K. (2013). Early Embryogenesis in Zebrafish Is Affected by Bisphenol A Exposure. Biol. Open 2, 466-471. doi:10. 1242/bio.20134283

Tsujikawa, M., and Malicki, J. (2004). Genetics of Photoreceptor Development and Function in Zebrafish. Int. J. Dev. Biol. 48, 925-934. doi:10.1387/ijdb.041890mt Uc-Peraza, R. G., Castro, Í. B., and Fillmann, G. (2022). An Absurd Scenario in 2021: Banned TBT-Based Antifouling Products Still Available on the Market. Sci. Total Environ. 805, 150377. doi:10.1016/j.scitotenv.2021.150377

Vancamp, P., Houbrechts, A. M., and Darras, V. M. (2019). Insights from Zebrafish Deficiency Models to Understand the Impact of Local Thyroid Hormone Regulator Action on Early Development. Gen. Comp. Endocrinol. 279, 45-52. doi:10.1016/j.ygcen.2018.09.011

Vandenberg, L. N., Chahoud, I., Heindel, J. J., Padmanabhan, V., Paumgartten, F. J., and Schoenfelder, G. (2010). Urinary, Circulating, and Tissue Biomonitoring Studies Indicate Widespread Exposure to Bisphenol A. Environ. Health Perspect. 118, 1055-1070. doi:10.1289/ehp.0901716

Vandenberg, L. N., Maffini, M. V., Sonnenschein, C., Rubin, B. S., and Soto, A. M. (2009). Bisphenol-A and the Great divide: a Review of Controversies in the Field of Endocrine Disruption. Endocr. Rev. 30, 75-95. doi:10.1210/er.20080021

Vasudevan, N., Koibuchi, N., Chin, W. W., and Pfaff, D. W. (2001). Differential Crosstalk between Estrogen Receptor (ER)alpha and ERbeta and the Thyroid Hormone Receptor Isoforms Results in Flexible Regulation of the Consensus ERE. Brain Res. Mol. Brain Res. 95, 9-17. doi:10.1016/s0169-328x(01)00165-6

Vasudevan, N., Ogawa, S., and Pfaff, D. (2002). Estrogen and Thyroid Hormone Receptor Interactions: Physiological Flexibility by Molecular Specificity. Physiol. Rev. 82, 923-944. doi:10.1152/physrev.00014.2002

Versonnen, B. J., and Janssen, C. R. (2004). Xenoestrogenic Effects of Ethinylestradiol in Zebrafish (Danio rerio). Environ. Toxicol. 19, 198-206. doi:10.1002/tox.20012

Vilela, C. L. S., Villela, H. D. M., Duarte, G. A. S., Santoro, E. P., Rachid, C. T. C. C., and Peixoto, R. S. (2021). Estrogen Induces Shift in Abundances of Specific Groups of the Coral Microbiome. Sci. Rep. 11, 2767. doi:10.1038/s41598-02182387-x

Vogalis, F., Shiraki, T., Kojima, D., Wada, Y., Nishiwaki, Y., Jarvinen, J. L., et al. (2011). Ectopic Expression of Cone-specific G-Protein-Coupled Receptor Kinase GRK7 in Zebrafish Rods Leads to Lower Photosensitivity and Altered Responses. J. Physiol. 589, 2321-2348. doi:10.1113/jphysiol.2010. 204156

Volkov, L. I., Kim-Han, J. S., Saunders, L. M., Poria, D., Hughes, A. E. O., Kefalov, V. J., et al. (2020). Thyroid Hormone Receptors Mediate Two Distinct Mechanisms of Long-Wavelength Vision. Proc. Natl. Acad. Sci. U S A. 117, 15262-15269. doi:10.1073/pnas.1920086117

Wada, K., Sakamoto, H., Nishikawa, K., Sakuma, S., Nakajima, A., Fujimoto, Y., et al. (2007). Life Style-Related Diseases of the Digestive System: Endocrine Disruptors Stimulate Lipid Accumulation in Target Cells Related to Metabolic Syndrome. J. Pharmacol. Sci. 105, 133-137. doi:10.1254/jphs.fm0070034

Wang, X., Dong, Q., Chen, Y., Jiang, H., Xiao, Q., Wang, Y., et al. (2013). Bisphenol A Affects Axonal Growth, Musculature and Motor Behavior in Developing Zebrafish. Aquat. Toxicol. 142-143, 104-113. doi:10.1016/j.aquatox.2013.07.011

Wang, Y. P., Hong, Q., Qin, D. N., Kou, C. Z., Zhang, C. M., Guo, M., et al. (2012). Effects of Embryonic Exposure to Polychlorinated Biphenyls on Zebrafish (Danio rerio) Retinal Development. J. Appl. Toxicol. 32, 186-193. doi:10. $1002 /$ jat. 1650

Weber, D. N., Hoffmann, R. G., Hoke, E. S., and Tanguay, R. L. (2015). Bisphenol A Exposure during Early Development Induces Sex-specific Changes in Adult Zebrafish Social Interactions. J. Toxicol. Environ. Health A. 78, 50-66. doi:10. $1080 / 15287394.2015 .958419$

Wolstenholme, J. T., Edwards, M., Shetty, S. R., Gatewood, J. D., Taylor, J. A., Rissman, E. F., et al. (2012). Gestational Exposure to Bisphenol A Produces Transgenerational Changes in Behaviors and Gene Expression. Endocrinology 153, 3828-3838. doi:10.1210/en.2012-1195

Yarwood, N. J., Gurr, J. A., Sheppard, M. C., and Franklyn, J. A. (1993). Estradiol Modulates Thyroid Hormone Regulation of the Human Glycoprotein Hormone Alpha Subunit Gene. J. Biol. Chem. 268, 21984-21989. doi:10. 1016/s0021-9258(20)80637-1 
Yu, W., Wu, N., Li, L., Wang, J., Ouyang, H., and Shen, H. (2020). Side Effects of PTU and MMI in the Treatment of Hyperthyroidism: a Systematic Review and Meta-Analysis. Endocr. Pract. 26, 207-217. doi:10.4158/EP-2019-0221

Zhang, C. N., Zhang, J. L., Ren, H. T., Zhou, B. H., Wu, Q. J., and Sun, P. (2017a). Effect of Tributyltin on Antioxidant Ability and Immune Responses of Zebrafish (Danio rerio). Ecotoxicol Environ. Saf. 138, 1-8. doi:10.1016/j. ecoenv.2016.12.016

Zhang, J., Zhang, C., Sun, P., Huang, M., Fan, M., and Liu, M. (2017b). RNAsequencing and Pathway Analysis Reveal Alteration of Hepatic Steroid Biosynthesis and Retinol Metabolism by Tributyltin Exposure in Male Rare Minnow (Gobiocypris Rarus). Aquat. Toxicol. 188, 109-118. doi:10.1016/j. aquatox.2017.03.015

Zoeller, R. T., Bansal, R., and Parris, C. (2005). Bisphenol-A, an Environmental Contaminant that Acts as a Thyroid Hormone Receptor Antagonist In Vitro, Increases Serum Thyroxine, and Alters RC3/neurogranin Expression in the Developing Rat Brain. Endocrinology 146, 607-612. doi:10.1210/en. 2004-1018
Conflict of Interest: The authors declare that the research was conducted in the absence of any commercial or financial relationships that could be construed as a potential conflict of interest.

Publisher's Note: All claims expressed in this article are solely those of the authors and do not necessarily represent those of their affiliated organizations, or those of the publisher, the editors and the reviewers. Any product that may be evaluated in this article, or claim that may be made by its manufacturer, is not guaranteed or endorsed by the publisher.

Copyright $\odot 2022$ Cohen, Popowitz, Delbridge-Perry, Rowe and Connaughton. This is an open-access article distributed under the terms of the Creative Commons Attribution License (CC BY). The use, distribution or reproduction in other forums is permitted, provided the original author(s) and the copyright owner(s) are credited and that the original publication in this journal is cited, in accordance with accepted academic practice. No use, distribution or reproduction is permitted which does not comply with these terms. 